\title{
FMRFamide Produces Biphasic Modulation of the LFS Motor Neurons in the Neural Circuit of the Siphon Withdrawal Reflex of Aplysia by Activating $\mathrm{Na}^{+}$and $\mathrm{K}^{+}$Currents
}

\author{
Kira J. Belkin and Thomas W. Abrams \\ Department of Biology and Institute of Neurological Sciences, University of Pennsylvania, Philadelphia, Pennsylvania \\ $19104-6018$
}

The molluscan neuropeptide FMRFamide has an inhibitory effect on transmitter release from the presynaptic sensory neurons in the neural circuit for the siphon withdrawal reflex. We have explored whether FMRFamide also acts postsynaptically in motor neurons in this circuit, focusing on the LFS motor neurons. FMRFamide typically produces a biphasic response in LFS neurons: a fast excitatory response followed by a prolonged inhibitory response. We have analyzed these postsynaptic actions and compared them with the mechanism of FMRFamide's inhibition of the presynaptic sensory neurons. The transient excitatory effect of FMRFamide, which desensitizes rapidly, is due to activation of a TTXinsensitive, $\mathrm{Na}^{+}$-dependent inward current. The late hyperpolarizing phase of the FMRFamide response results from activation of at least two $\mathrm{K}^{+}$currents. One component of the hyperpolarizing response is active at rest and at more hyperpolarized membrane potentials, and is blocked by $5 \mathrm{~mm}$ 4-aminopyridine, suggesting that it differs from the previously described FMRFamide-modulated $K^{+}$currents in the presynaptic sensory neurons. In addition, FMRFamide increases a 4-aminopyridine-insensitive $K^{+}$current.

Presynaptically, FMRFamide increases $K^{+}$conductance, acting via release of arachidonic acid. In the LFS motor neurons, application of arachidonic acid mimicked the prolonged, hyperpolarizing phase of the FMRFamide response; 4-bromophenacyl bromide, an inhibitor of phospholipase $A_{2}$, selectively blocked this component of the FMRFamide response. Thus, FMRFamide may act in parallel pre- and postsynaptically to inhibit the output of the siphon withdrawal reflex circuit, producing this inhibitory effect via the same second messenger in the sensory neurons and motor neurons, though a number of the $\mathrm{K}+$ currents modulated in these two types of neurons are different.

[Key words: arachidonic acid, neuropeptides, neuromodulation]

A wide variety of behaviors in both vertebrates and invertebrates are produced by simple reflex pathways or central pattern generators. The ability of animals to modify reflexive and rhyth-

\footnotetext{
Received Aug. 20, 1992; revised May 26, 1993; accepted June 2, 1993.

We thank Sol Erulkar, Marc Dichter, Bruce Goldsmith, and Marc Klein for helpful discussions and for critically reading and commenting on the manuscript.

Correspondence should be addressed to Dr. Thomas W. Abrams, Department of Biology, University of Pennsylvania, Philadelphia, PA 19104-6018.

Copyright $\odot 1993$ Society for Neuroscience $0270-6474 / 93 / 135139-14 \$ 05.00 / 0$
}

mic behaviors as a consequence of experience indicates that the functional output of neural circuits underlying behaviors can be altered, either through modulation of existing circuits or through rewiring. In several systems, modulatory inputs exert parallel effects at multiple sites within a single neural circuit. For example, in the feeding system of Aplysia californica, the scrotonergic metacerebral cell, which has modulatory effects on interneurons, motor neurons, and a muscle that is involved in biting behavior, acts in parallel at these various loci to increase the rate and intensity of the biting response (Weiss et al., 1978; Rosen et al., 1989). In the lobster stomatogastric ganglion, the neuropeptide proctolin increases the amplitude and frequency of bursting activity of multiple neurons in the neural circuits underlying both the pyloric and gastric rhythms (Marder and Meyrand, 1989; Selverston, 1989). In the neural circuit mediating defensive inking behavior in Aplysia, serotonin (5-HT) modulates both the sensory neurons and the postsynaptic ink motor neurons, acting in parallel to enhance the behavioral response (Klein and Kandel, 1980; Walsh and Byrne, 1985; Dale and Kandel, 1990).

Behavioral modification of the defensive gill and siphon withdrawal reflex of Aplysia californica also involves modulation at several sites of the neural circuit. Novel stimuli, such as strong electrical shock to the tail, cause sensitization of the reflex (Carew et al., 1981b). During sensitization, facilitation of the synaptic connection between siphon sensory neurons and gill and siphon motor neurons occurs in parallel with, and contributes to, enhancement of the withdrawal reflex (Castellucci et al., 1970; Castellucci and Kandel, 1976; Carew et al., 1981a). These changes in the sensory neuron to motor neuron synaptic connections in response to tail shock are largely due to presynaptic changes. The primary facilitatory transmitter released by tail shock is 5-HT (Glanzman et al., 1989; Hawkins, 1989; Mackey et al., 1989; Mercer et al., 1991). 5-HT's facilitatory effects on the presynaptic sensory neurons include a decrease in spike threshold, spike broadening, and an increase in transmitter release (Brunelli et al., 1976; Castellucci and Kandel, 1976; Klein and Kandel, 1980; Walters et al., 1983; Klein et al., 1986; Dale and Kandel, 1990). Recently, it has been found that inhibitory inputs also have important modulatory effects on the magnitude of the withdrawal reflex (Mackey et al., 1987; Marcus et al., 1988; Krontiris et al., 1989; Wright et al., 1991; Small et al., 1992; Trudeau and Castellucci, 1992; Fischer and Carew, 1993), and at least one mechanism of behavioral inhibition involves presynaptic modulation of transmitter release from the siphon sensory neurons (Mackey et al., 1987). 
However, plasticity in this circuit is not restricted to the sensory neurons. During sensitization, modulation of interneurons and motor neurons of this same withdrawal reflex circuit has also been described (Hawkins et al., 1981; Frost et al., 1988; Wright et al., 1991; Trudeau and Castellucci, 1992; Fischer and Carew, 1993). One class of siphon motor neurons that undergoes modulation is the LFS motor neurons, which receive both monosynaptic and polysynaptic input from the LE siphon sensory neurons (Frost et al., 1988). Tail shock produces a prolonged increase in the tonic firing rate of the LFS neurons, lasting several minutes. Exogenously applied 5-HT has a similar excitatory modulatory effect on the LFS neurons. Thus, the facilitatory transmitter 5-HT has parallel effects on both sensory and motor neurons of the siphon withdrawal neural circuit, facilitating presynaptic transmitter release and increasing excitability postsynaptically.

The molluscan tetrapeptide FMRFamide is known to have multiple inhibitory effects on mechanosensory neurons. These effects have been studied in detail both in the siphon sensory neurons in the abdominal ganglion and in the sensory neurons of the VC cluster of the pleural ganglion. [These two populations of sensory neurons have similar physiological properties, including their responses to FMRFamide (Abrams et al., 1984; Belardetti et al., 1987; Piomelli et al., 1987) and to the facilitatory transmitters 5-HT (Klein and Kandel, 1980; Bernier et al., 1982; Klein et al., 1982; Walters et al., 1983; Ocorr and Byrne, 1985; Pollock et al., 1985) and the small cardioactive neuropeptides $\mathrm{SCP}_{\mathrm{A}}$ and $\mathrm{SCP}_{\mathrm{B}}$ (Abrams et al., 1984; Ocorr and Byrne, 1985; Pieroni and Byrne, 1992; Jarrard et al., 1993).] FMRFamide causes an increase in spike threshold of the sensory neurons, narrowing of the sensory neuron action potential (Abrams et al., 1984; Pieroni and Byrne, 1992), and a decrease in the sensory neuron-to-motor neuron excitatory PSP (Abrams et al., 1984; Piomelli et al., 1987). FMRFamide has direct effects on transmitter release, causing a reduction in spontaneous release from sensory neurons (Dale and Kandel, 1990). The peptide also causes a decrease in protein phosphorylation, and acts to reverse the phosphorylation effects of 5-HT (Sweatt et al., 1989); moreover, FMRFamide antagonizes a 5-HT-induced facilitatory process that is independent of spike broadening (Dale and Kandel, 1990; Pieroni and Byrne, 1992).

FMRFamide produces its effects on sensory neuron membrane properties through the modulation of multiple channel types. The peptide causes an increased activation of several $\mathrm{K}^{+}$ currents, including the S-K+ current (Belardetti et al., 1987; Critz et al., 1991) and a steeply voltage-dependent $\mathrm{K}^{+}$current $I_{\mathrm{K} \cdot \mathrm{v} \text {,early }}\left(\right.$ or $\left.I_{\mathrm{K}-\mathrm{v}}\right)$ (Critz et al., 1991), first described by Baxter and Byrne (1989). In addition, FMRFamide causes a decrease in the $\mathrm{Ca}^{2+}$-dependent $\mathrm{K}^{+}$current in these cells (Critz et al., 1991), activates a $\mathrm{Cl}^{-}$current (Buttner and Siegelbaum, 1990; Armitage et al., 1991), and reduces a $\mathrm{Ca}^{2+}$ current (Edmonds et al., 1990). The effects of FMRFamide on the $\mathrm{K}^{+}$currents appear to be mediated by the arachidonic acid family of second messengers; FMRFamide stimulates arachidonic acid release by phospholipase $A_{2}$ in sensory neurons (Piomelli et al., 1987) and application of arachidonic acid mimics the effects of FMRFamide on all of these $\mathrm{K}^{+}$currents (Piomelli et al., 1987; Critz et al., 1991). Lipoxygenase metabolites of arachidonic acid have been demonstrated to mimic the effect of FMRFamide on the S-K $\mathrm{K}^{+}$ channels of Aplysia sensory neurons (Belardetti et al., 1987, 1989; Piomelli et al., 1987; Buttner et al., 1989).

We have found that FMRFamide exerts inhibitory effects on the postsynaptic LFS siphon motor neurons that parallel its presynaptic actions. FMRFamide modulates multiple ionic currents in the LFS neurons. We have asked whether FMRFamide acts via the same cellular mechanisms postsynaptically, modulating the same $\mathrm{K}^{+}$currents via the arachidonic acid cascade as it does presynaptically. The cellular mechanisms underlying the FMRFamide response in LFS neurons are distinct from those that mediate its effects on the presynaptic sensory neurons in several respects. However, there is some similarity in the second messenger systems involved at the pre- and postsynaptic sites, since arachidonic acid appears to mediate one component of the response to FMRFamide in the LFS neurons.

\section{Materials and Methods}

Abdominal ganglia were removed from 100-200 gm Aplysia californica (obtained from Marinus, Long Beach, CA, and Alacrity, Redondo Beach, CA) that had been anesthetized by injection of isotonic ( $360 \mathrm{mM}) \mathrm{MgCl}_{2}$. Ganglia were placed in a $0.5 \%$ solution of glutaraldehyde for $45 \mathrm{sec}$ to prevent contraction of muscle in the sheath. The left ventral hemiganglion was desheathed in a 1:1 mixture of isotonic $\mathrm{MgCl}_{2}$ and normal saline. During experiments, ganglia were superfused with physiological saline containing $10 \mathrm{~mm}$ HEPES ( $\mathrm{pH} 7.6$ ), $7 \mathrm{~mm}$ glucose, minimum essential medium (MEM), essential and nonessential amino acids $(0.2 \times$ normal concentration; GIBCO Laboratories), and MEM vitamin solution ( $0.7 \times$ normal concentration; GIBCO Laboratories). The composition of salts in the culture medium varied according to the specific experimental protocol (Table 1).

Intracellular recordings were made with 6-12 $\mathrm{M} \Omega$ microelectrodes filled with either $2 \mathrm{M} \mathrm{KCl}$ or $2 \mathrm{~m}$ potassium acetate. In experiments studying the contribution of $\mathrm{Cl}^{-}$currents to the FMRFamide response, microelectrodes were filled with $2 \mathrm{M}$ potassium acetate to avoid altering $\left[\mathrm{Cl}^{-}\right]_{i}$. An Axoclamp 2A amplifier (Axon Instruments) was used for current clamp and single-electrode and two-electrode voltage clamp. For current-clamp recordings, membrane potential was altered by injection of current via the bridge circuit. For single-electrode voltage clamp, a single electrode cycled between a voltage recording mode $(70 \%$ of the cycle) and a current passing mode ( $30 \%$ of the cycle) at $4-8 \mathrm{kHz}$, depending on the time constant of the individual neuron. Unless otherwise indicated, single-electrode voltage clamp was used for all voltageclamp experiments. FMR Famide responses were typically studied with a holding potential of $-60 \mathrm{mV}$. Data were digitized with an $A / D$ board (DT 2821, Data Translation, Marlboro, MA), and analyzed using the software programs spike (Hilal Associates, Englewood Cliffs, NJ) and IGOR (Wavemetrics, Lake Oswego, OR).

The reversal potential of the late phase of the response was measured by giving $10 \mathrm{sec}$ puffs of FMRFamide at various holding potentials and observing the polarity of the response at the end of the puff; the holding potential was varied in $2 \mathrm{mV}$ increments in the range in which the response reversed. Membrane conductance was determined by voltage clamping the cell and recording the change in current in response to a $300 \mathrm{msec}, 15 \mathrm{mV}$ hyperpolarizing voltage step, prior to and during the FMRFamide response.

The LFS motor neurons were identified by their morphological and physiological properties. LFS neurons are located on the left ventral surface of the ganglion, near the exit point of the siphon nerve, in the cluster of small $(40-60 \mu \mathrm{m})$ neurons that also contains the LE siphon scnsory ncurons. Both LFS and LE ncurons' axons are activated directly by siphon nerve stimulation. The LFS neurons are distinguishable from these sensory neurons and from other nearby previously described neurons with axons in the siphon nerve by several of their unique electrophysiological characteristics. (1) LFS neurons fire repetitively at rest at a low frequency $(<1 \mathrm{~Hz})$. (2) LFS neurons exhibit a characteristic response to the removal of hyperpolarizing current, in which there is a dip or inflection in the membrane potential as the neuron depolarizes. [This inflection has the appearance of a hyperpolarization that results from transient activation of an A-K ${ }^{+}$current (Connor and Stevens, 1971).] (3) LFS neurons are further distinguishable from other neighboring motor neurons with axons in the siphon nerve by having a low background level of synaptic input and lacking substantial interneuron II input (Perlman, 1979). In contrast to the LFS motor neurons, the LE ncurons do not fire spontancously, and cxhibit rapid spike accommo- 
Table 1. Ionic concentrations of salines

\begin{tabular}{|c|c|c|c|c|c|c|}
\hline Type of saline & $\mathrm{NaCl}_{2}$ & $\mathrm{KCl}$ & $\mathrm{CaCl}_{2}$ & $\mathrm{MgCl}_{2}$ & $\begin{array}{l}\text { Na- } \\
\text { HEPES } \\
\end{array}$ & Addition \\
\hline Normal saline & $460 \mathrm{~mm}$ & $10 \mathrm{~mm}$ & $11 \mathrm{~mm}$ & $55 \mathrm{~mm}$ & $10 \mathrm{~mm}$ & \\
\hline $\begin{array}{l}\text { Low sodium (Tris } \\
\text { substituted) }\end{array}$ & $108 \mathrm{~mm}$ & $10 \mathrm{~mm}$ & $11 \mathrm{~mm}$ & $55 \mathrm{~mm}$ & $10 \mathrm{~mm}$ & $352 \mathrm{~mm}$ Tris $\mathrm{Cl}$ \\
\hline $\begin{array}{l}\text { Low sodium } \\
\text { ( } N \text {-methyl-D-glucamine } \\
\text { substituted) }\end{array}$ & $108 \mathrm{~mm}$ & $10 \mathrm{~mm}$ & $11 \mathrm{~mm}$ & $55 \mathrm{~mm}$ & $10 \mathrm{~mm}$ & $\begin{array}{l}352 \text { mм } N- \\
\text { methyl-D- } \\
\text { glucamine }\end{array}$ \\
\hline High potassium & $430 \mathrm{~mm}$ & $30 \mathrm{~mm}$ & $11 \mathrm{~mm}$ & $55 \mathrm{~mm}$ & $10 \mathrm{~mm}$ & \\
\hline $10^{-7} \mathrm{M}$ calcium & $460 \mathrm{~mm}$ & $10 \mathrm{~mm}$ & $1 \mathrm{~mm}$ & $55 \mathrm{~mm}$ & $10 \mathrm{~mm}$ & $3 \mathrm{~mm}$ EGTA \\
\hline Barium substituted & $460 \mathrm{~mm}$ & $10 \mathrm{~mm}$ & $0 \mathrm{~mm}$ & $55 \mathrm{~mm}$ & $10 \mathrm{~mm}$ & $11 \mathrm{mM} \mathrm{BaCl}_{2}$ \\
\hline High divalent & $230 \mathrm{~mm}$ & $10 \mathrm{~mm}$ & $110 \mathrm{~mm}$ & $110 \mathrm{~mm}$ & $10 \mathrm{~mm}$ & \\
\hline
\end{tabular}

dation, generally firing only one or two action potentials at the onset of a prolonged depolarizing step.

LFS neurons can be subdivided into LFS-A and LFS-B neurons, according to the direction of siphon movement elicited (Frost et al., 1988). To distinguish between LFS neuron subtypes, we presented 5 sec, $10 \mathrm{~Hz}$ trains of $2 \mathrm{msec}$ electrical stimuli to the branchial nerve. Preliminary studies of Fang and Clark suggested that LFS-A and B cells differ somewhat in the magnitude of their adaptation to prolonged branchial nerve stimulation, though this distinction is not definitive (X. Fang and G. Clark, personal communication). Following a brief onset of firing, LFS-B cells frequently stop firing completely during the first second of maintained branchial nerve stimulation, or they continue to fire at a slower rate; LFS-As show a more modest adaptation, but very rarely stop firing completely. During the course of this study, we frequently categorized LFS neurons based on the magnitude of adaptation during maintained branchial nerve stimulation as a criterion for distinguishing between subtypes. Although this criterion does not reliably distinguish LFS-As from LFS-Bs, completely adapting LFS neurons are almost always LFS-Bs. We should note, however, that it is possible that some of the LFS-like neurons with axons in the siphon nerve that we studied might not have been classified as either A or B subtypes had we determined the siphon movements produced.

FMRFamide $(2 \mu \mathrm{M})$ or arachidonic acid was applied by pressure ejection from pipettes with $8-10 \mu \mathrm{m}$ tips, which were positioned approximately one cell body diameter away from the neuron being monitored. FMRFamide and arachidonic acid were dissolved in the same saline that bathed the ganglion. Puff pipettes were backfilled by capillary action.

Tetraethylammonium (TEA; Eastman Kodak), tetrodotoxin (TTX; Calbiochem), and 4-aminopyridine (4-AP; Sigma) were all dissolved directly into the appropriate extracellular medium. A $1000 \times$ concentration of 4-bromophenacyl bromide (Sigma) was prepared in dimethyl sulfoxide and aliquots were stored at $-20^{\circ} \mathrm{C}$. A $25 \mu \mathrm{M}$ concentration of arachidonic acid ( $\mathrm{Nu}$-Chek Prep) was prepared in either toluene or ethanol. Aliquots were immediately transferred to amber glass vials, which were filled with nitrogen and stored at $-70^{\circ} \mathrm{C}$. Immediately prior to use, $1-2 \mu$ l of arachidonic acid was dried with nitrogen and then brought to the final concentration in saline and sonicated. Every effort was taken to minimize the time that the arachidonic acid was exposed to air.

Statistical analyses were done with a two-tailed $t$ test, unless otherwise noted. The criterion for statistical significance was $p<0.05$. All averaged data are expressed as mean \pm standard error of the mean. In most cases, statistical comparisons were of the within-preparation differences produced by the treatment, using a paired $t$ test. For data presented as ratios, statistical comparisons were of the arcsine transformations of the ratios.

\section{Results}

FMRFamide had a biphasic, predominately inhibitory effect on the majority of LFS neurons. A transient depolarization and an increase in firing rate were followed by a prolonged membrane hyperpolarization and suppression of the spike activity (see Fig. 1). The hyperpolarization showed little or no decay during the
$10 \mathrm{sec}$ puff of FMRFamide; the membrane potential gradually returned to rest over tens of seconds following the end of the puff. The early transient depolarization component of the response was more easily observed when the cell's spontaneous firing was suppressed by either hyperpolarizing the cell below fring threshold or bathing the ganglion in high- $\mathrm{Ca}^{2+} / \mathrm{high}-\mathrm{Mg}^{2+}$ saline (Fig. 1B).

LFS neurons have been divided into two categories-LFS-A and LFS-B cells. These two subpopulations initiate siphon movements of different directionality (Frost et al., 1988; Hickie and Walters, 1990,1991), and they respond differently to tail shock, peripheral nerve stimulation, and connective stimulation (Frost et al., 1988; Fang and Clark, 1990, 1992; Hickie and

\section{A. At $\mathrm{V}_{\text {rest }}$}

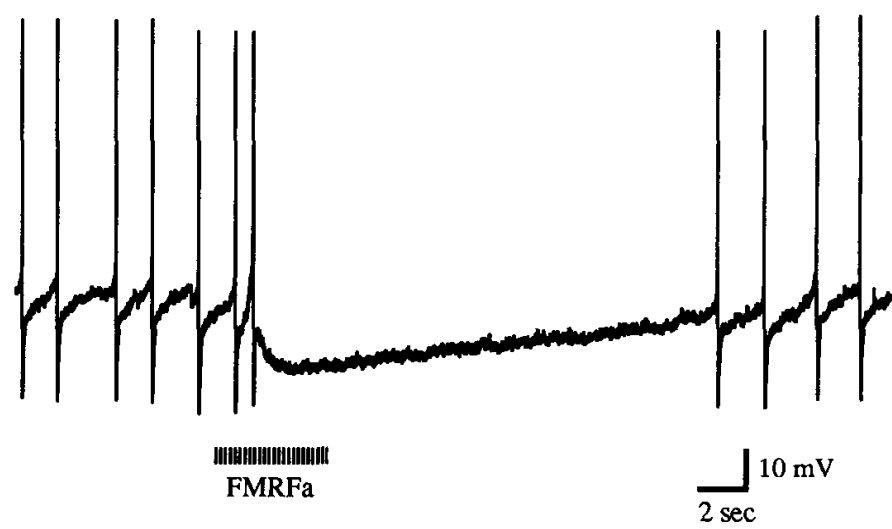

B. Hyperpolarized

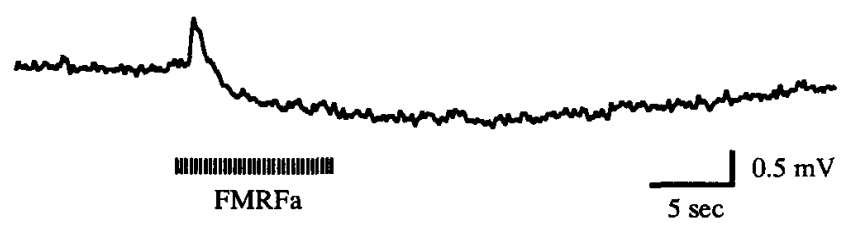

Figure 1. Response of LFS neurons to FMRFamide. $A$, Response of spontaneously active LFS neuron to $10 \mathrm{sec}$ puff of $2 \mu \mathrm{M}$ FMRFamide. Note that FMRFamide initially produced a transient increase in firing rate, followed by a prolonged hypcrpolarization and suppression of spontaneous firing. $B$, Response of LFS neuron to similar puff of FMRFamide when neuron is hyperpolarized below firing threshold. Neurons in $A$ and $B$ are from different preparations. 
Modestly Adapting LFS Neuron

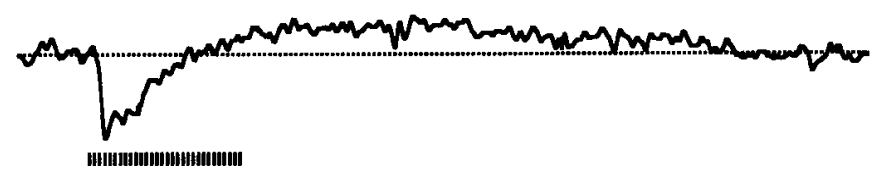

FMRFa

Completely Adapting LFS Neuron

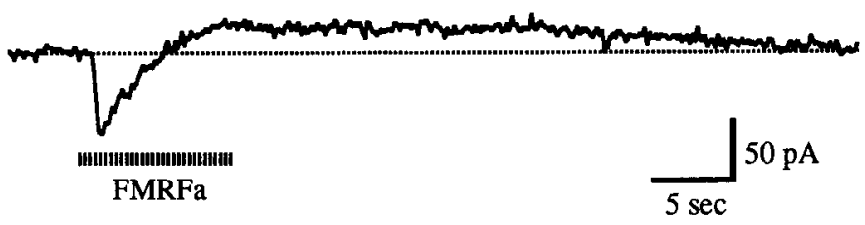

Figure 2. LFS neurons with different responses to branchial nerve stimulation have similar responses to FMRFamide. Responses of each cell type to FMRFamide were measured under voltage clamp. Holding potential was $-60 \mathrm{mV}$. Dotted line indicates holding current before the onset of the $10 \mathrm{sec}$ FMRFamide puff. All records are from different cells.

Walters, 1990, 1991). We divided LFS neurons into two groups based on their responses to maintained $10 \mathrm{~Hz}$ branchial nerve stimulation: rapidly and completely adapting (with a complete cessation of firing after the first second of maintained stimulation) or modestly adapting. According to the characterization of Fang and Clark (personal communication), this difference in adaptation partially correlates with LFS-A and LFS-B subtypes; LFS-Bs are often, though not always, completely adapting during maintained branchial nerve stimulation, while LFS-As are almost never completely adapting. We found that approximately $50 \%$ of LFS neurons tested (30 of 63 neurons) were rapidly adapting. LFS-Bs account for approximately five-eighths of the total number of LFS neurons (C. Hickic and E. T. Walters, personal communication); therefore, we would estimate that, although most of the modestly adapting neurons are LFS-As, a minority (perhaps $25 \%$ ) are LFS-Bs. A majority (>70\%) of both rapidly adapting and modestly adapting LFS neurons exhibited the typical biphasic response to FMRFamide described above (Fig. 2), and we have therefore pooled data from studies of the two cell types.

A minority of LFS neurons exhibited an atypical exclusively excitatory response to FMRFamide. This response to the peptide occurred in fewer than $20 \%$ of the LFS neurons studied throughout most of the year (October-May); however, during the summer months of June-September, FMRFamide caused a prolonged excitatory response in greater than $50 \%$ of the LFS neurons. The distribution of these different response types among individual neurons did not correlate with the two categories of responses to branchial nerve stimulation; the group of neurons
Normal Saline

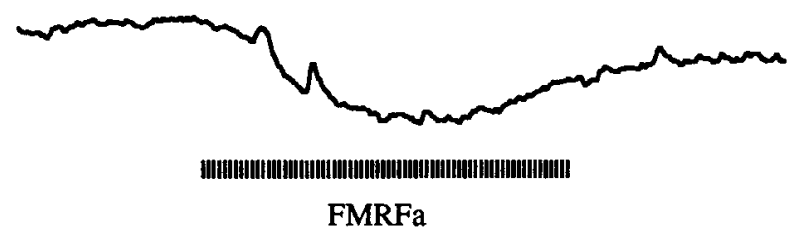

Low $\mathrm{Na}^{+}$Saline

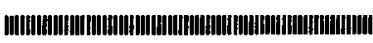

FMRFa

Normal Saline

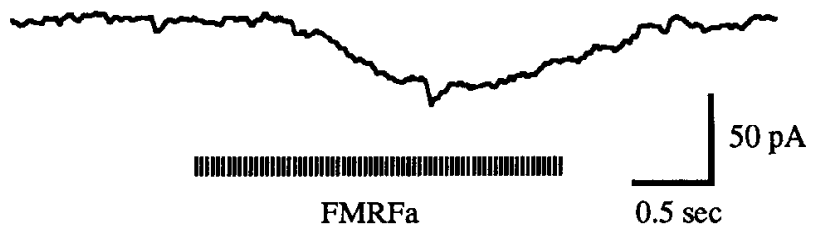

Figure 3. Effect of reduced external $\mathrm{Na}^{+}$on the transient inward current component of the FMRFamide response. The response to a $2 \mathrm{sec}$ FMRFamide puff was first recorded in normal saline (top trace), then when the ganglion was superfused with saline in which $N$-methyl-Dglucamine was substituted for $75 \%$ of the external $\mathrm{Na}^{+}$(middle trace), and finally after the ganglion was returned to normal saline (bottom trace). Membrane potential was clamped at $-70 \mathrm{mV}$.

that completely adapted to branchial stimulation, which we can be relatively confident are LFS-B neurons, exhibited both types of responses to FMRFamide. The "summer" response of LFS neurons to FMRFamide will be described in a separate report (K. J. Belkin and T. W. Abrams, unpublished observations). The analysis presented below is restricted to neurons exhibiting the more typical, transient excitatory/prolonged inhibitory response.

To determine whether the LFS neurons' response to FMRFamide was partly due to activation of other neurons presynaptic to the motor neurons, we examined the FMRFamide response while neuronal firing threshold was elevated with high divalent saline (Table 1), or while action potentials were blocked with TTX. The response to FMRFamide in the presence of either $10 \times \mathrm{Ca}^{2+} / 2 \times \mathrm{Mg}^{2+}$ saline $(n=10)$ or $100 \mu \mathrm{M}$ TTX $(n$ $=8$ ) was similar to the response observed in normal saline.

Early inward current is mediated by increase In $\mathrm{Na}^{+}$ conductance

The early inward current component of the FMRFamide response desensitized with repeated presentation of $10 \mathrm{sec}$ puffs of $2 \mu \mathrm{M}$ FMRFamide. Therefore, in order to analyze the ionic basis of the early component, we presented brief $2 \mathrm{sec}$ puffs of FMRFamide, with a minimum of 2 min between puffs. No decrement in the magnitude of the early component was observed with this protocol. The early inward current component of the FMRFamide response was associated with an increase in resting membrane conductance of $2.5 \pm 0.5 \mathrm{nS}(n=5)$ (measured $2 \mathrm{sec}$ after the onset of the puff). The short puff was 
sufficient to activate the prolonged phase of the response, which typically began after the end of the puff; we do not know whether this is due to long-lasting effects of FMRFamide or to slow washout of the peptide.

To test whether the early inward current resulted from an increase in $\mathrm{Na}^{+}$conductance, we substituted either Tris or $N$-methyl-D-glucaminc for $\mathrm{Na}^{+}$. A $75 \%$ reduction in external $\mathrm{Na}^{+}$caused a significant, $86.6 \pm 8.5 \%$ reduction in the magnitude of the early inward current ( $p<0.01, n=6$; Fig. 3), indicating that this early phase of the response was mediated by an increase in $\mathrm{Na}^{+}$conductance. A qualitatively similar decrease in the early transient response in reduced external $\mathrm{Na}^{+}$ was observed in two additional preparations studied under current clamp. This reduction in the early inward current is substantially greater than would be predicted if the early current were carried exclusively by $\mathrm{Na}^{+}$ions (assuming an intracellular $\mathrm{Na}^{+}$concentration of $50 \mathrm{mM}$, in $25 \%$ normal $\mathrm{Na}^{+}, E_{\mathrm{Na}}$ would be $+20 \mathrm{mV}$, which represents only a $31 \%$ decrease in driving force for $\mathrm{Na}^{+}$at a membrane potential of $-60 \mathrm{mV}$ ). The fact that the decrease in external $\mathrm{Na}^{+}$nearly eliminated the early inward current must mean that during the early phase of the response, there is also a substantial outward current (such that the net current in low $\mathrm{Na}^{+}$is close to zero). The magnitude of the early inward current was not reduced by $100 \mu \mathrm{M}$ TTX (mean early current $=-25 \pm 0.8 \mathrm{pA}$ in TTX compared with $-24 \pm$ $3.3 \mathrm{pA}$ in control saline, $n=3$ ).

\section{Late hyperpolarization due to an increase in $\mathrm{K}^{+}$conductance}

The late outward current component of the response to FMRFamide involved an increase in membrane conductance of $3.4 \pm 1.2 \mathrm{nS}(n=12)$ (measured at the end of the $10 \mathrm{sec}$ puff). The outward current reversed when the membrane potential was clamped at holding potentials negative to rest (Fig. 4). In normal saline, the average reversal potential of the late phase of the FMRFamide response was $-74.6 \pm 1.03$ ( $n$ = 33).

A threefold increase in the external $\mathrm{K}^{+}$concentration caused a substantial reduction in the late outward current component of the FMRFamide response, resulting in a significant shift in reversal potential from $-73.3 \pm 2.4 \mathrm{mV}$ to $-51.9 \pm 5.0 \mathrm{mV}$ $(p<0.01, n=4)$. This $21 \mathrm{mV}$ change in reversal potential is only $76 \%$ of the value predicted by the Nernst equation assuming the prolonged current were carried exclusively by $\mathrm{K}^{+}$ions. This suggests that this phase of the FMRFamide response was partially, but not entirely, mediated by an increase in $\mathrm{K}^{+}$conductance.

We wished to investigate whether FMRFamide modifies the same $\mathrm{K}^{+}$channel types in the postsynaptic LFS motor neurons as in the presynaptic sensory neurons. As described above, FMRFamide modulates at least three different $\mathrm{K}^{+}$currents in Aplysia sensory neurons, causing (1) an increase in the S-K+ current, $I_{\mathrm{K}-\mathrm{s}}$, (2) an increase in the voltage-dependent, inactivating $\mathrm{K}^{+}$current, $I_{\mathrm{K}-\mathrm{v} \text {,early }}$, and (3) a decrease in the $\mathrm{Ca}^{2+}$-dependent $\mathrm{K}^{+}$current, $I_{\mathrm{K}-\mathrm{Ca}}$ (Piomelli et al., 1987; Critz et al., 1991). These various $\mathrm{K}^{+}$currents can be distinguished by both pharmacological and kinetic characteristics (Table 2). $I_{\mathrm{K}-\mathrm{V} \text {,early }}$ is steeply voltage-dependent, activating at potentials positive to $-10 \mathrm{mV}$, and rapidly inactivates. $I_{\mathrm{K}-\mathrm{v} \text {,early }}$ is sensitive to low concentrations of 4-AP and is completely blocked by $1 \mathrm{mM}$ 4-AP (Baxter and Byrne, 1989). This current is also blocked by relatively high concentrations of TEA, with $K_{d}=8 \mathrm{~mm}$ (Baxter and Byrne, 1989). The modulated $\mathrm{Ca}^{2+}$-dependent $\mathrm{K}^{+}$current

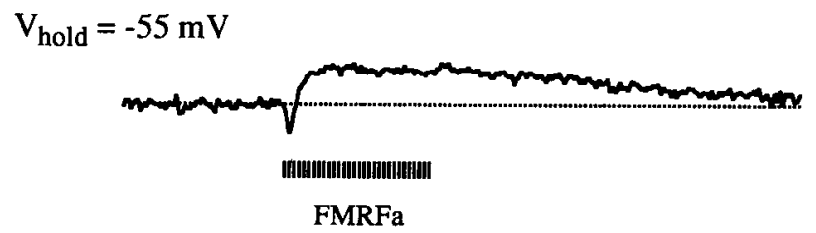

$V_{\text {hold }}=-70 \mathrm{mV}$

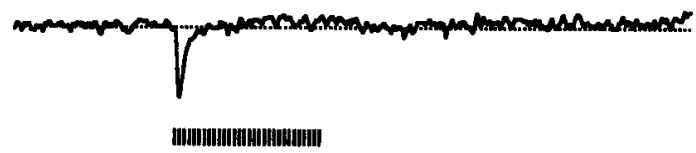

FMRFa

$\mathrm{V}_{\text {hold }}=-75 \mathrm{mV}$

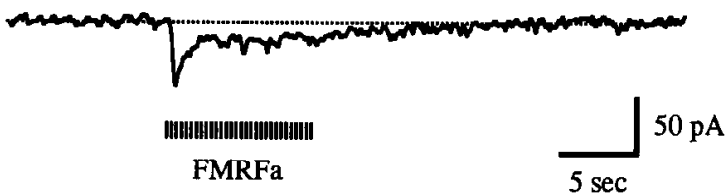

Figure 4. Reversal of prolonged component of FMRFamide response with change in holding potential. Note that at a holding potential $\left(V_{\text {hold }}\right)$ of $-70 \mathrm{mV}$, the late component of the FMRFamide response reverses polarity.

is a voltage-dependent, noninactivating current which is blocked by low concentrations of TEA $\left(K_{d}=0.5 \mathrm{~mm}\right)$, but is unaffected by $1 \mathrm{~mm}$ 4-AP (Hermann and Gorman, 1981a,b; Baxter and Byrne, 1989; Walsh and Byrne, 1989; Critz et al., 1991). The $\mathrm{S}-\mathrm{K}^{+}$current consists of two distinct components, a slowly activating, noninactivating component, and a time-independent (or very rapidly activating) component that is active at rest (Klein et al., 1982; Goldsmith and Abrams, 1992). The single channel S-K+ current, studied by Siegelbaum et al. (1982) and Shuster ct al. (1991), probably corresponds to the time-independent component of the macroscopic current. Both components of the S-K ${ }^{+}$current are increased by FMRFamide (Belardetti et al., 1987; Piomelli et al., 1987; Critz et al., 1991). The two components of the S-K $\mathrm{K}^{+}$current are relatively voltageindependent and are TEA-insensitive (Klein et al., 1982; Siegelbaum et al., 1982; Pollock et al., 1985; Shuster and Siegelbaum, 1987; Shuster et al., 1991). Single S-K+ channels are also insensitive to $5 \mathrm{~mm}$ 4-AP (Shuster and Siegelbaum, 1987). However, the effect of 4-AP on the slowly activating component of the current had not previously been determined.

We therefore measured the effect of 4-AP on the slowly activating S-K ${ }^{+}$current of Aplysia pleural sensory neurons. As discussed above, pleural ganglion sensory neurons have electrophysiological and pharmacological properties similar to the LE siphon sensory neurons of the abdominal ganglion, and the characteristics of the macroscopic $\mathrm{S}-\mathrm{K}^{+}$current are identical in the two groups of sensory neurons (Klein et al., 1982; Pollock et al., 1985); 5 mM 4-AP was not effective in blocking the slowly activating, noninactivating, outward current component of the 5-HT response in the sensory neurons (Fig. 5). Thus, both the macroscopic slowly activating $\mathrm{S}-\mathrm{K}^{+}$current, and the time-independent $\mathrm{S}-\mathrm{K}^{+}$current recorded at the single channel level, are insensitive to 5 mm 4-AP. 
Table 2. Summary of kinetic and pharmacological properties of $\mathrm{K}^{+}$currents modulated by FMRFamide in the LE and VC sensory neurons.

\begin{tabular}{|c|c|c|c|c|}
\hline & Voltage dependence & Kinetics & 4-AP sensitivity & TEA sensitivity \\
\hline$I_{\mathrm{K}-\mathrm{v}, \text { early }}$ & $\begin{array}{l}\text { Steeply voltage dependent, } \\
\text { active at } V_{m}>-10 \mathrm{mV}^{a}\end{array}$ & $\begin{array}{l}\text { Rapidly activating, } \\
\text { inactivating }\end{array}$ & Blocked by $1 \mathrm{mM}^{a}$ & $K_{d}=8 \mathrm{mM}^{a}$ \\
\hline$I_{\mathrm{K} \cdot \mathrm{Ca}}$ & $\mathrm{Yes}^{a, b}$ & $\begin{array}{l}\mathrm{Ca}^{2+} \text {-dependent activation, } \\
\text { noninactivating }\end{array}$ & No effect of $1 \mathrm{mM}^{a, c}$ & $\begin{array}{c}K_{d}=0.5 \mathrm{mM}^{a, d}(\text { voltage- } \\
\text { dependent block) }\end{array}$ \\
\hline$I_{\mathrm{K}-\mathrm{s}}:$ slowly activating & Modest ${ }^{e}$ & $\begin{array}{l}\text { Slowly activating, } \\
\text { noninactivating }\end{array}$ & No effect of $5 \mathrm{~mm}^{\prime}$ & No effect of $50 \mathrm{~mm}^{8}$ \\
\hline $\begin{array}{l}I_{\mathrm{K}-\mathrm{s}}: \text { single channel } \\
\text { (steady state) }\end{array}$ & Modest $^{h, i}$ & $\begin{array}{l}\text { Time independent, or very } \\
\text { rapidly activating, } \\
\text { noninactivating }\end{array}$ & No effect of $10 \mathrm{~mm}^{\prime}$ & $K_{d}=90 \mathrm{~mm}^{j}$ \\
\hline
\end{tabular}

\footnotetext{
"Baxter and Byrne, 1989.

b Walsh and Byrne, 1989.

Hermann and Gorman, 1981a.

${ }^{\circ}$ Hermann and Gorman, 1981 b.

"Klein et al., 1982.

see Figure 5.

$s$ Pollock et al., 1985.

${ }^{\text {h }}$ Siegelbaum et al., 1982.

Shuster et al., 1991.

Shuster and Siegelbaum, 1987.
}

We began our analysis of the $\mathrm{K}^{+}$currents modulated by FMRFamide in LFS neurons by determining the sensitivity of the outward current component of the FMRFamide response to the $\mathrm{K}^{+}$channel blockers TEA and 4-AP. All experiments involving TEA were conducted while the ganglion was superfused with high-divalent saline to prevent a barrage of postsynaptic potentials onto the LFS neurons. The outward current component of the prolonged phase of the FMRFamide response in LFS neurons was insensitive to $50 \mathrm{mM}$ TEA (Fig. 6A). This was observed in four preparations. In contrast, $5 \mathrm{~mm} \mathrm{4-AP}$ blocked this late outward current, and unmasked an inward component of the prolonged phase of the FMRFamide response (blockade of the late outward current by 4-AP was observed in 25 preparations) (Fig. $6 B$ ). The sensitivity to 4-AP (Fig. 7) suggests that the $\mathrm{K}^{+}$current modulated by FMRFamide is distinct from the $\mathrm{S}-\mathrm{K}^{+}$current. Furthermore, the insensitivity of this outward current to $50 \mathrm{mM}$ TEA suggests that it is distinct from $I_{\mathrm{K} \text {-ca }}$, and from $I_{\mathrm{K} \text {-.early }}$ as well. Therefore, FMRFamide appears to modulate a 4-AP-sensitive $\mathrm{K}^{+}$current in LFS neurons that is not activated by the peptide in the presynaptic sensory neurons.

We wished to detcrminc whether FMRFamide, in addition to activating a 4-AP-sensitive $\mathrm{K}^{+}$current, also modulated $\mathrm{K}^{+}$ currents in the LFS neurons that are not active at rest, such as $I_{\mathrm{K}-\mathrm{V} \text {.early }}$ or $I_{\mathrm{K} \cdot \mathrm{Ca}}$ (Critz et al., 1991). In the sensory neurons, FMRFamide causes narrowing of the action potential, probably due to its increasing $I_{\mathrm{K}-\mathrm{v} \text {,early }}$ and the time-independent component of $\mathrm{I}_{\mathrm{K}-\mathrm{S}}$ (Belardetti et al., 1987; Critz et al., 1991). Although we did not assess the FMRFamide modulation of these currents directly, we asked whether FMRFamide produces a similar change in action potential shape in the LFS neurons. We hyperpolarized LFS neurons below firing threshold, and elicited action potentials with $2 \mathrm{msec}$ pulses of positive current. The membrane potential was held at a constant value in both normal saline and during the FMRFamide puff. FMRFamide had no significant effect on either the height or width of the action potentials of LFS neurons ( $n=5$; Fig. 8). Since $I_{\text {K-v,early }}$ plays a substantial role in repolarizing the action potential, at least in the sensory neurons (Byrne et al., 1990), this lack of change in action potential shape suggests that there is little or no modulation of this current by FMRFamide.

We also wished to determine whether FMRFamide modulates the $\mathrm{Ca}^{2+}$-dependent $\mathrm{K}^{+}$current in LFS neurons, as it does in sensory neurons (Critz et al., 1991). At membrane potentials close to rest, $I_{\mathrm{K}-\mathrm{Ca}}$ is active only when intracellular $\mathrm{Ca}^{2+}$ levels are elevated, for example, during prolonged activity or depolarization or during experimental injection of $\mathrm{Ca}^{2+}$ (Thompson, 1977; Hermann and Gorman, $1981 \mathrm{~b}$; Walsh and Byrne, 1989). Therefore, we chose to study the effect of FMRFamide on $I_{\mathrm{K} \text {-Ca }}$ indirectly, by examining the effects of the peptide on repetitive firing behavior during long trains of action potentials that would elevate intracellular $\mathrm{Ca}^{2+}$.

The firing rate of LFS neurons during prolonged depolarizing current pulses declines or accommodates over the course of several seconds. In a variety of neurons, accommodation results from activation of $I_{\mathrm{K}-\mathrm{Ca}}$ (e.g., Yarom et al., 1985). To test whether the accommodation in LFS neurons was also mediated by $I_{\mathrm{K}}$ $\mathrm{Ca}$, we compared the rates of accommodation in both normal and $\mathrm{Ba}^{2+}$-substituted saline. To quantify accommodation, we calculated an "accommodation ratio," the instantaneous firing frequency (or inverse of the time interval between two spikes) at the end of a $5 \mathrm{sec}$ depolarizing pulse divided by the initial instantaneous firing frequency. (An accommodation ratio of 1 would reflect no change in firing frequency.) Substituting $\mathrm{Ba}^{2+}$ for $\mathrm{Ca}^{2+}$ in the saline resulted in a significant decrease in accommodation [an accommodation ratio of $0.79 \pm 0.06$ in $\mathrm{Ba}^{2+}$ saline $(n=7)$, compared with an accommodation ratio of 0.55 \pm 0.04 in normal saline $(n=12 ; p<0.02)]$ (Fig. 9). The dependence of accommodation on extracellular $\mathrm{Ca}^{2+}$ is consistent with a mechanism involving $I_{\mathrm{K} \text {-ca }}$.

FMRFamide caused a very modest, but significant, increase in spike accommodation; the accommodation ratio was reduced by $0.053 \pm 0.02$ during the FMRFamide puff $(p<0.05, n=$ 12; Fig. $9 B$ ), changing from $0.55 \pm 0.04$ in normal saline to $0.50 \pm 0.04$ in FMRFamide. FMRFamide did not significantly increase accommodation when the ganglion was perfused with 
A. Normal Saline

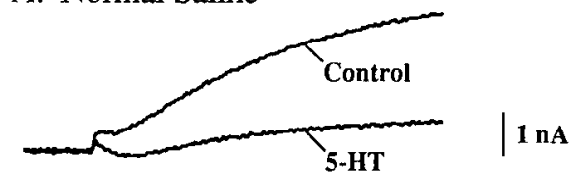

B. 4-AP

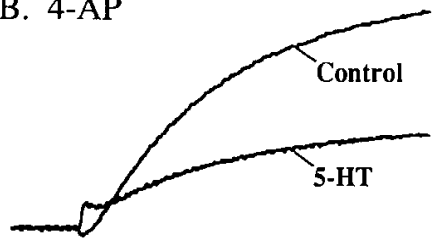

| 1 nA

\section{Difference Currents}

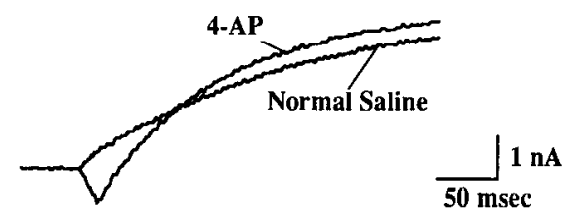

Figure 5. 4-AP does not block the slowly activating 5-HT-sensitive $\mathrm{K}^{+}$current in sensory neurons. $I_{\mathrm{K} . \mathrm{s}}$ was studied in pleural sensory neurons by stepping the membrane potential to $-20 \mathrm{mV}$ from a holding potential of $-50 \mathrm{mV}$ in control saline or with $20 \mu \mathrm{M} 5-\mathrm{HT}$ in the absence $(A)$ or the presence $(B)$ of 4-AP. After the first exposurc to $5-\mathrm{HT}$, the transmitter was washed out of the bath and approximately 60 min later was applied in the presence of 5 mM 4-AP. C, 5-HT-modulated current. Difference currents were calculated by subtracting the current in the presence of 5-HT from the current in the absence of 5-HT. Records were corrected for leakage current measured at $-70 \mathrm{mV}$. The small increase in initial outward current with $5-\mathrm{HT}$ in $4-\mathrm{AP}$, seen in $B$ and $C$, was not a typical response.

$\mathrm{Ba}^{2+}$-substituted saline (in $\mathrm{Ba}^{2+}$-substituted saline the accommodation ratio increased $+0.013 \pm 0.017$ with FMRFamide, $n=7$ ) (Fig. 9B). These observations suggest that the increase in accommodation induced by FMRFamide results either from a small increase in $I_{\mathrm{K}-\mathrm{Ca}}$ or from an increase in $\mathrm{Ca}^{2+}$ influx. Thus, FMRFamide did not appear to decrease $I_{\mathrm{K}-\mathrm{Ca}}$ as it does in the sensory neurons.

\section{A. TEA Sensitivity}

High Divalent Saline

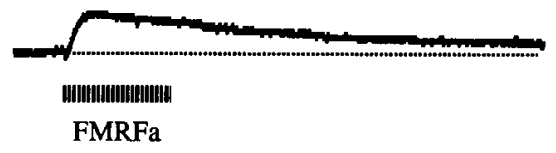

$50 \mathrm{mM}$ TEA in High Divalent Saline

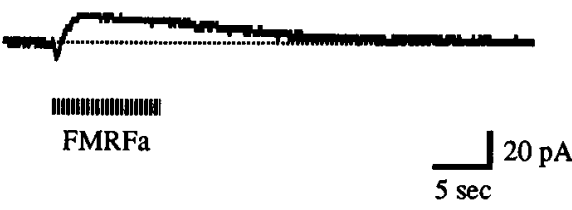

B. 4-AP Sensitivity

Normal Saline

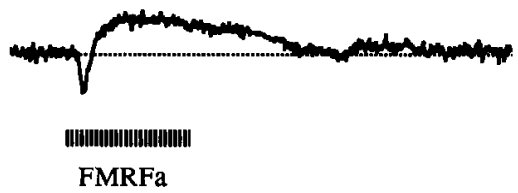

$5 \mathrm{mM} 4-\mathrm{AP}$ in Normal Saline

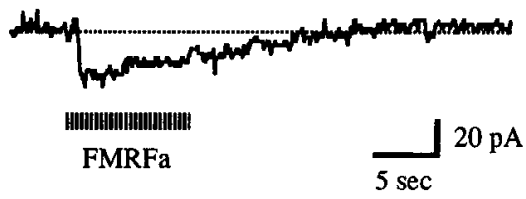

Figure 6. Effect of TEA and 4-AP on responses of LFS neurons to FMRFamide. $A$, Response of an LFS neuron to a FMRFamide puff in the absence and presence of $50 \mathrm{~mm}$ TEA. Experiment was conducted in high divalent saline $\left(10 \times\right.$ normal $\mathrm{Ca}^{2+}, 2 \times$ normal $\left.\mathrm{Mg}^{2+}\right)$ in order to prevent elevated synaptic input that results from perfusion with TEA. Membrane potential was clamped at $-53 \mathrm{mV}$, the cell's resting potential in high divalent saline. $B$, Effect of 4-AP on the prolonged outward current component of the FMRFamide response. The response of an LFS neuron to a FMRFamide puff was recorded in both normal saline and in $5 \mathrm{~mm}$ 4-AP. Note that 4-AP had no effect on the early component of the response, but decreased the late outward current and unmasked a prolonged inward current component. Membrane potential was clamped at $-60 \mathrm{mV}$. Similar effects of 4-AP were observed in 24 additional preparations. $A$ and $B$ are from different preparations. 

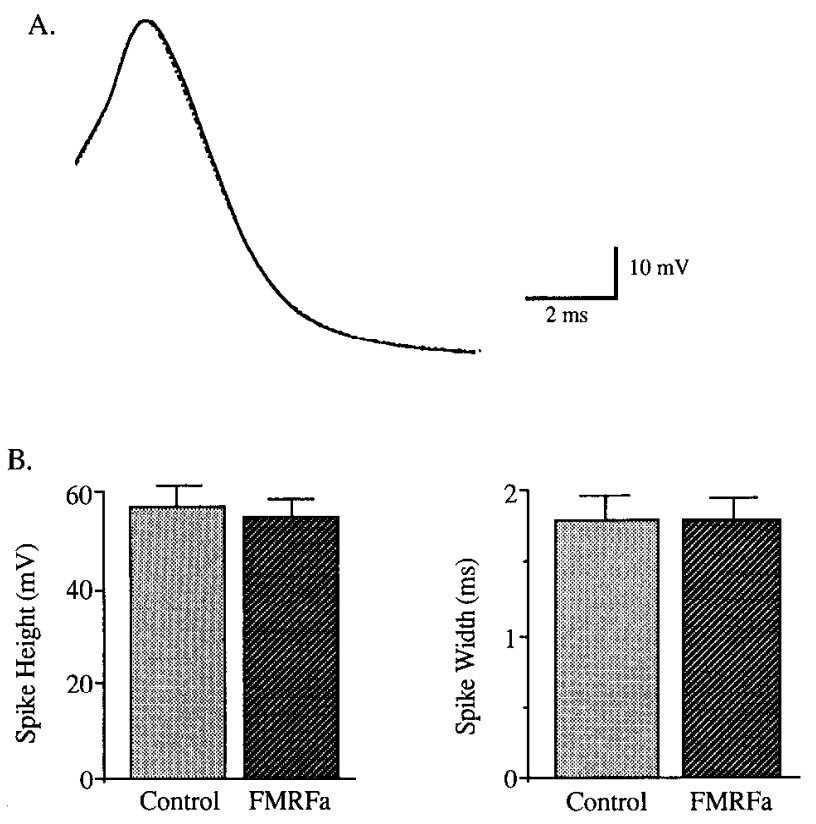

Figure 8. Action potential shape is unaffected by FMRFamide. $A$, Superimposed action potentials recorded in normal saline (solid line) and during FMRFamide puff (broken line). LFS neurons were hyperpolarized to below firing threshold, and action potentials were stimulated with brief 2 msec pulses of positive current. Membrane potential was held at a constant value in these experiments, both in normal saline and during the FMRFamide puff. $B$, Average action potential amplitude and width in both normal saline and during FMRFamide puff $(n=5)$. Height is amplitude relative to baseline. Width was measured from the peak of the spike to the point at which membrane potential had declined to $33 \%$ of the peak value.

volves activation of an inward current carried by $\mathrm{Na}^{+}$, as well as an activation of an outward $\mathrm{K}^{+}$current. This observation is consistent with our previous conclusion, based on the dependence of the FMRFamide response on the extracellular $\mathrm{K}^{+}$concentration, that the late component is only partially due to modulation of $\mathrm{K}^{+}$current; $100 \mu \mathrm{M}$ TTX had no measurablc effcct

Figure 9. FMRFamide produces a small enhancement of $\mathrm{Ca}^{2+}$-dependent spike frequency adaptation in LFS motor neurons. $A, \mathrm{Ca}^{2+}$ dependence of spike frequency adaptation: adaptation in normal saline and in saline with $\mathrm{Ba}^{2+}$ substituted for extracellular $\mathrm{Ca}^{2+}$. Note that adaptation is greatly reduced in $\mathrm{Ba}^{2+}$-substituted saline. Cell was hyperpolarized to $-60 \mathrm{mV}$ to prevent spontaneous firing, and then injected with a $5 \mathrm{sec}$ depolarizing current step of sufficient magnitude to induce an initial firing rate of $10 \mathrm{~Hz} . B$, Average effect of FMRFamide on accommodation ratio. FMRFamide produced a small but significant decrease in the accommodation ratio (the firing frequency at the end of the $5 \mathrm{sec}$ current pulse $\div$ the frequency at the beginning of the pulse) in normal saline $(*, p<0.05, t$ test on within preparation diffcrences, $n=12$ ). There was no significant effect of FMRFamide on accommodation in $\mathrm{Ba}^{2+}$-substituted saline $(n=7)$.

A. Normal Saline on the prolonged component of the response ( $n=3$, data not shown), indicating that the $\mathrm{Na}^{+}$current activated during the late component of the FMRFamide response was TTX-insensitive.

In the presence of $5 \mathrm{~mm} 4-\mathrm{AP}$ and $25 \%$ external $\mathrm{Na}^{+}$, the overall response to FMRFamide was highly variable. In 7 of 13 LFS ncurons, FMRFamide had a substantial hyperpolarizing effect under these conditions (Fig. 10). For example, of the cells with this hyperpolarizing response that were studied under voltage clamp, the magnitude of this outward current at $-60 \mathrm{mV}$ was $35 \pm 8.3 \mathrm{pA}(n=4)$. This indicates that in some LFS neurons FMRFamide activated an additional outward current, which was 4-AP-insensitive. In the remaining preparations, although reducing extracellular $\mathrm{Na}^{+}$caused a decrease in the inward current component of the prolonged phase of the response, FMRFamide still had a depolarizing effect in reduced extracellular $\mathrm{Na}^{+}$and 4-AP. This could mean either that the 4-APinsensitive outward current was absent in these neurons, or simply made a relatively smaller contribution to the response.

\section{FMRFamide does not activate a $\mathrm{Ca}^{2+}$ current}

To determine whether FMRFamide caused a change in $\mathrm{Ca}^{2+}$ conductance, we comparcd the responses to FMRFamide in normal saline and in low- $\mathrm{Ca}^{2+}$ saline (with a free $\mathrm{Ca}^{2+}$ concentration of approximately $10^{-7} \mathrm{M}$; Table 1 ). Reducing external $\mathrm{Ca}^{2+}$ had no significant effect on the early component of the FMRFamide response (magnitude of the early inward current was $-49.2 \pm 8.5 \mathrm{pA}$ in $10^{-7} \mathrm{M} \mathrm{Ca}^{2+}$, compared with $-53.4 \pm$ $12.2 \mathrm{pA}$ in normal saline, $n=4$ ). Reducing extracellular $\mathrm{Ca}^{2+}$ also had no significant effect on the prolonged component of the FMRFamide response in either normal saline $(n=3)$ (Fig. $11)$ or $5 \mathrm{mM} \mathrm{4-AP}(n=3)$.

\section{FMRFamide does not activate a $\mathrm{Cl}^{-}$current}

It has been demonstrated that FMRFamide activates a $\mathrm{Cl}^{-}$conductance in Aplysia mechanosensory neurons (Buttner and Siegelbaum, 1990; Armitage et al., 1991). To determine whether FMRFamide activates a $\mathrm{Cl}^{-}$conductance in LFS neurons, we substituted $77 \%$ of external $\mathrm{Cl}^{-}$with methane sulfonate. We observed that reducing the extracellular $\mathrm{Cl}^{-}$concentration had no effect on the magnitude of the FMRFamide response or on

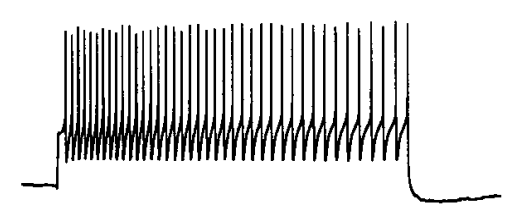

Barium Substituted Saline

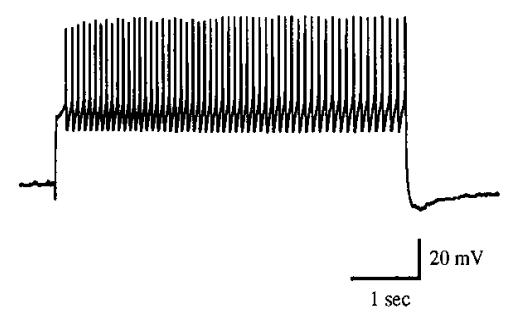

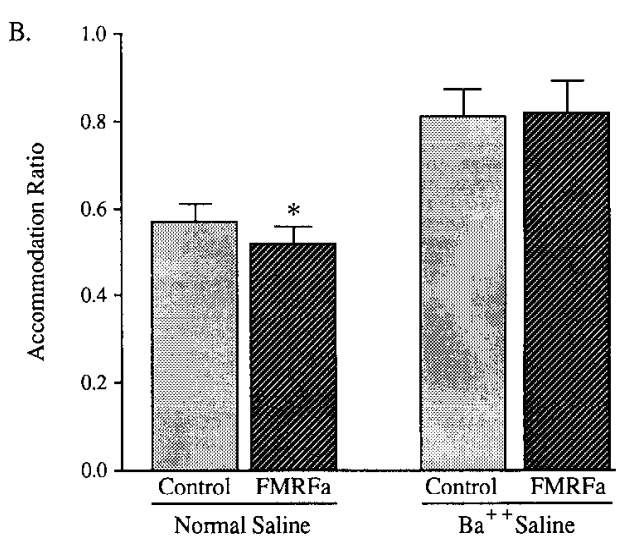


$5 \mathrm{mM} 4-\mathrm{AP}$

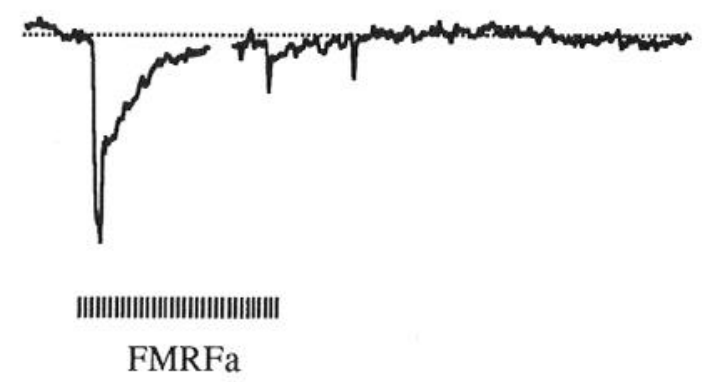

5 mM 4-AP in Low Sodium Saline
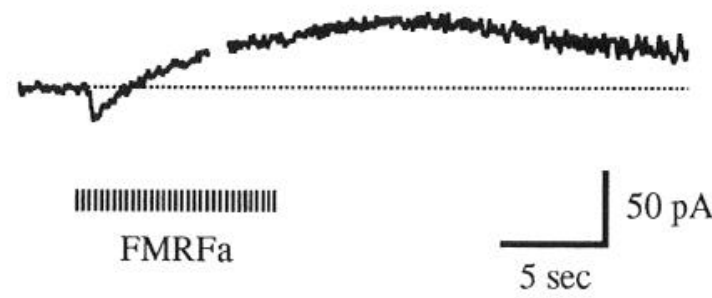

Figure 10. $\mathrm{Na}^{+}$dependence of the prolonged component of the FMRFamide response. In the presence of $5 \mathrm{~mm}$ 4-AP, FMRFamide induced an inward current, which decayed throughout the duration of the $10 \mathrm{sec}$ puff. Both the early and late components of the inward current response were decreased in low- $\mathrm{Na}^{+}$saline ( $25 \%$ normal), and a 4-APinsensitive outward current was unmasked. In the presence of $5 \mathrm{~mm}$ 4-AP, this LFS neuron had an unusually small inward current during the prolonged phase of the response (compare Fig. 6). Holding potential was $-60 \mathrm{mV}$. (The $300 \mathrm{msec}$ gap in each current trace is due to a negative voltage step used to test membrane conductance. These steps in current are not shown because they exceed the limits of the figure.)

its reversal potential in nine experiments (Fig. 11), including three in which the response was studied in the presence of $25 \%$ $\mathrm{Na}^{+}$and 5 mм 4-AP.

\section{Arachidonic acid mimics hyperpolarizing effects of FMRFamide}

Several lines of evidence suggest that arachidonic acid production is part of the second messenger cascade mediating the re-

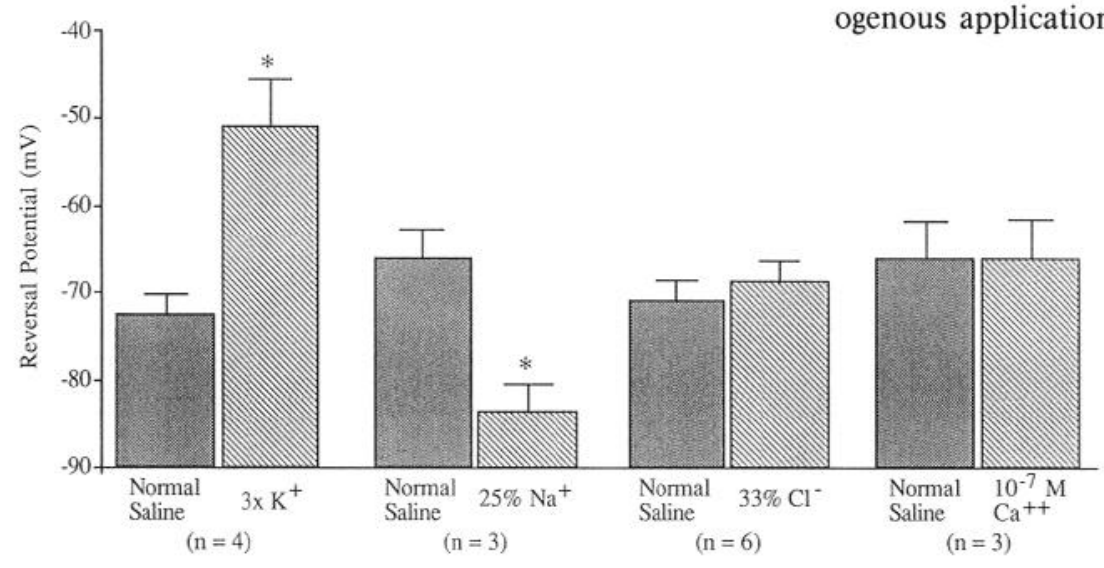

Figure 12. Response of LFS neurons to arachidonic acid. A, Response to $5 \mathrm{sec}$ puff of $40 \mu \mathrm{m}$ arachidonic acid $(A A)$. $B$, Response to $15 \mathrm{sec}$ puff of $40 \mu \mathrm{M}$ arachidonic acid. Cell in $B$ was hyperpolarized to $-65 \mathrm{mV}$ to prevent spontaneous firing. (In this and the next figure, gaps in voltage records are during injected pulses of negative current used to test input resistance.) $A$ and $B$ are different cells.

sponse to FMRFamide in the presynaptic sensory neurons. For example, arachidonic acid mimics the modulatory effect of FMRFamide on $\mathrm{K}^{+}$conductance in sensory neurons (Belardetti et al., 1987; Piomelli et al., 1987; Critz et al., 1991), and the phospholipase $\mathrm{A}_{2}$ inhibitor 4-bromophenacyl bromide inhibits the effect of FMRFamide (Piomelli et al., 1987). We therefore asked whether arachidonic acid plays a similar role in FMRFamide modulation of the postsynaptic LFS neuron. Exof 30-50 $\mu \mathrm{M}$ arachidonic acid mimicked 


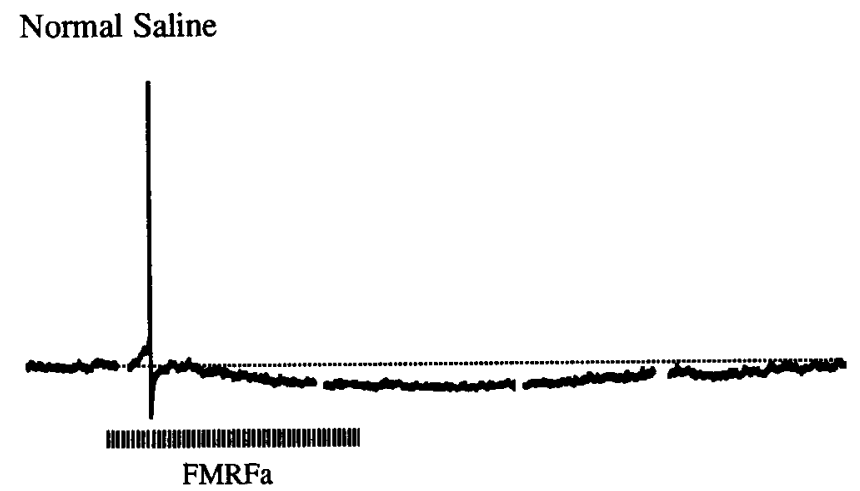

$100 \mu \mathrm{M}$ 4-Bromophenacyl Bromide

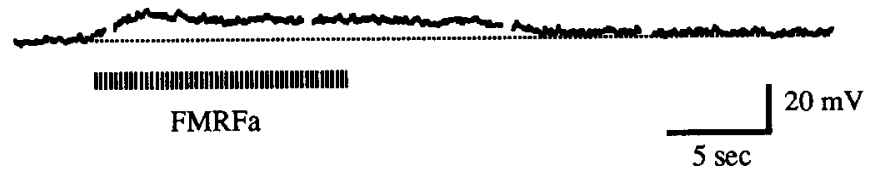

Figure 13. Effect of 4-bromophenacyl bromide on response of LFS neurons to FMRFamide. Cell was hyperpolarized to $-65 \mathrm{mV}$ to prevent spontancous firing.

the prolonged, hyperpolarized phase of the FMRFamide response in LFS neurons, but not the early, transient depolarization (Fig. 12). In order to test whether FMRFamide might produce its effects by activating the enzyme phospholipase $A_{2}$, and thus stimulating the release of arachidonic acid from membrane phospholipids, we perfused the ganglion with $100 \mu \mathrm{M}$ 4-bromophenacyl bromide, an inhibitor of phospholipase $A_{2}$. 4-Bromophenacyl bromide selectively blocked the late hyperpolarizing component of the FMRFamide response in six of eight LFS neurons; in the presence of 4-bromophenacyl bromide, the early transient depolarization was enhanced and prolonged (Fig. 13). The effect of 4-bromophenacyl bromide was not reversible. These observations are consistent with the possibility that arachidonic acid or a metabolite of arachidonic acid is the second messenger mediating a component of the response of LFS neurons to FMRFamide, causing activation of one or more $\mathrm{K}^{+}$currents. However, 4-bromophenacyl bromide has at least one nonspecific effect on LFS neurons, since bathing the ganglion in $100 \mu \mathrm{M}$ 4-bromophenacyl bromide blocked or slowed their spontaneous firing rate.

\section{Discussion}

These experiments have characterized a biphasic modulatory action of the neuropeptide FMRFamide on LFS siphon motor neurons. The FMRFamide response consists of a transient, desensitizing depolarization, followed by a prolonged hyperpolarization. The major effect of FMRFamide on LFS motor neurons is inhibitory, paralleling its inhibitory effect on the presynaptic siphon sensory neurons. Thus, the peptide has complementary actions at two distinct loci within the siphon withdrawal reflex neural pathway. FMRFamide exerts its inhibitory effect on LFS neurons through the activation of multiple cellular mechanisms, which regulate multiple ionic currents. There are several similarities between the modulatory effects of FMRFamide on the LFS motor neurons and the siphon sensory neurons; however, the mechanisms mediating the response of these two cell types are not identical.

Because FMRFamide was puffed onto the cell body of the LFS neuron in the intact ganglion, it is possible that some of the effects we observed were due to FMRFamidergic effects on other neurons that synapse onto the LFS neurons. However, the response to FMRFamide is most likely due to direct actions on the LFS neurons since FMRFamide exerts modulatory effects on LFS neurons in both high divalent saline and in TTX, conditions in which input from interneurons would be greatly reduced. Nevertheless, because FMRFamide causes an increase in production of arachidonic acid in the sensory neurons (Piomelli et al., 1987), and because arachidonic acid is known to act as an intercellular messenger in other systems (Hedqvist, 1977), it is possible that the effects of presynaptic release of arachidonic acid might contribute to the modulation of LFS neurons that we have described.

\section{FMRFamide modulation of $\mathrm{Na}^{+}$conductance}

An increase in a TTX-insensitive $\mathrm{Na}^{+}$current is responsible for the early, transient phase of the FMRFamide response (Fig. 3). This inward current appears to be voltage-independent in the range we have studied, -50 to $-90 \mathrm{mV}$. The observation that the decrease in inward current with a reduction in extracellular $\mathrm{Na}^{+}$was larger than predicted suggests that the current in the early phase of the response includes a substantial increase in $\mathrm{K}^{+}$conductance as well as $\mathrm{Na}^{+}$conductance. The transient current activated by FMRFamide is likely to represent a mixed $\mathrm{Na}^{+}-\mathrm{K}^{+}$current; moreover, the outward currents that comprise the prolonged phase of the response may be somewhat activated during the early phase.

There are two possible explanations for the decay of the early component of the response. One explanation is desensitization of either a receptor subtype or an element in the cascade coupling the receptor to the ion channel. Another possibility is that the inward $\mathrm{Na}^{+}$current does not decline rapidly, but is masked by the slower increase in outward $\mathrm{K}^{+}$current. In the presence of either 4-AP or 4-bromophenacyl bromide, both of which block the prolonged outward current component of the FMRFamide response, there is still a decay in the initial depolarizing component of the response to FMRFamide (Figs. 10, 13). These observations suggest that this early increase in $\mathrm{Na}^{+}$conductance desensitizes over a time course of several seconds.

The prolonged phase of the FMRFamide response is sensitive to a reduction in external $\mathrm{Na}^{+}$concentration (Fig. 10), indicating that this phase of the response also involves activation of a $\mathrm{Na}^{+}$ conductance. This inward current appears to be voltage-independent, since we observed no voltage dependence of the late phase of the response in the range we have studied, -50 to -90 $\mathrm{mV}$. We have not determined whether this prolonged $\mathrm{Na}^{+}$current, which is also TTX insensitive, is distinct from that activated during the initial component of the FMRFamide response. The $\mathrm{Na}^{+}$current during the prolonged phase of the FMRFamide response could in principle represent a residual component of the $\mathrm{Na}^{+}$current activated in the early phase of the response which has desensitized. However, the fact that we have frequently observed desensitization of the early component of the response after repeated $10 \mathrm{sec}$ puffs of FMRFamide, with no corresponding change in reversal potential of the prolonged component, suggests that there are, in fact, two distinct $\mathrm{Na}^{+}$ currents being modulated.

Modulation of $\mathrm{Na}^{+}$conductance by FMRFamide in the pre- 
synaptic sensory neurons has not been reported by previous investigators. Therefore, the modulation of $\mathrm{Na}^{+}$conductance by FMRFamide in LFS motor neurons represents one difference in the cellular actions of FMRFamide at these two sites of the neural circuit.

\section{FMRFamide modulation of $\mathrm{K}^{+}$conductances}

As is true for the presynaptic sensory neurons, FMRFamide exerts an inhibitory effect on LFS motor neurons by causing an increase in multiple types of $\mathrm{K}^{+}$currents. The sensitivity of the FMRFamide response to changes in external $\mathrm{K}^{+}$provides evidence that a component of the late outward current is carried by $\mathrm{K}^{+}$. This increase in $\mathrm{K}^{+}$current is substantially blocked by $5 \mathrm{~mm}$ 4-AP (Figs. 6, 7). In the presence of $5 \mathrm{~mm} 4$-AP and low external $\mathrm{Na}^{+}(25 \%$ of normal), FMRFamide induced a late hyperpolarizing outward current in approximately half of the LFS neurons we studied (Fig. 10). Because $5 \mathrm{~mm} 4$-AP is a near maximal concentration for blocking the 4-AP-sensitive component (Fig. 7), this additional outward current unmasked in 4-AP and low $\mathrm{Na}^{+}$probably represents a 4 -AP-insensitive $\mathrm{K}^{+}$ current. Thus, FMRFamide appears to activate two distinct $\mathrm{K}^{+}$ currents in at least some of the LFS neurons, one 4-AP sensitive and one 4-AP insensitive.

The 4-AP-sensitive current that we have observed appears to be distinct from any of the FMRFamide modulated outward currents that have been identified in sensory neurons. Unlike $I_{\mathrm{K}-\mathrm{Ca}}$ and $I_{\mathrm{K}-\mathrm{v} \text {,early }}$, the 4-AP-sensitive outward current we have studied is insensitive to $50 \mathrm{~mm}$ TEA (Fig. 6). The fact that this current is active near the resting membrane potential also suggests that it is distinct from these other two $\mathrm{K}^{+}$currents. This FMRFamide-activated, 4-AP-sensitive, $\mathrm{K}^{+}$current is also distinct from $I_{\mathrm{K}-\mathrm{s}}$, since the latter is minimally affected by $5 \mathrm{~mm}$ 4-AP (Shuster and Siegelbaum, 1987, and Fig. 5). Therefore, we conclude that FMRFamide activates a 4-AP-sensitive $\mathrm{K}^{+}$ current that is not modulated by the peptide in the sensory ncurons.

FMRFamide produces a very modest increase in $\mathrm{Ca}^{2+}$-dependent spike frequency adaptation or accommodation (Fig. 9). This increase in accommodation could in principle be a consequence of one of three effects of FMRFamide on LFS neuron currents: (1) an increase in $I_{\mathrm{K}, \mathrm{Ca}},(2)$ an increase in $I_{\mathrm{Ca}}$, or (3) an increase in $\mathrm{Ca}^{2+}$ influx that occurs secondarily as a result of spike broadening due to a reduction in $\mathrm{K}^{+}$current. The third alternative is not a plausible explanation since FMRFamide neither increases the spike duration (Fig. 8) nor produces an obvious reduction in $\mathrm{K}^{+}$current in LFS neurons. We cannot distinguish between the first two alternatives. In any case, FMRFamide does not appear to increase the $\mathrm{Ca}^{2+}$-dependent $\mathrm{K}^{+}$current as it does in the presynaptic sensory neurons (Critz et al., 1991).

\section{Response to FMRFamide is independent of external $\mathrm{Ca}^{2+}$ and} $\mathrm{Cl}^{-}$concentrations

The response of LFS cells to FMRFamide showed no sensitivity to external $\mathrm{Ca}^{2+}$ (Fig. 11), suggesting that the prolonged component of the FMRFamide response that we studied does not involve modulation of a $\mathrm{Ca}^{2+}$ conductance. Edmonds et al. (1990) have demonstrated that FMRFamide reduces a dihydropyridine-insensitive $\mathrm{Ca}^{2+}$ current in Aplysia sensory neurons. We are unable to conclude whether FMRFamide also modulates this $\mathrm{Ca}^{2+}$ current in LFS neurons, since we did not record at the depolarized membrane potentials at which this current is active.

Previous studies on the sensory neurons (Buttner and Siegelbaum, 1990; Armitage et al., 1991) have observed that FMRFamide modulates a $\mathrm{Cl}^{-}$channel that is active at hyperpolarized membrane potentials. A threefold decrease in extracellular $\mathrm{Cl}^{-}$had no effect on the response of LFS neurons to FMRFamide at hyperpolarized membrane potentials, indicating that this $\mathrm{Cl}^{-}$current is not modulated by FMRFamide in the postsynaptic motor neurons (Fig. 11).

\section{Role of arachidonic acid in mediating FMRFamide response}

Evidence suggests that the arachidonic acid cascade mediates the effects of FMRFamide on $\mathrm{K}^{+}$currents in the presynaptic sensory neurons (Piomelli et al., 1987; Critz et al., 1991). Arachidonic acid also appears to mediate a component of the FMRFamide response in LFS neurons. Arachidonic acid mimics the prolonged hyperpolarizing component of the FMRFamide response (Fig. 12), and the phospholipase $A_{2}$ inhibitor 4-bromophenacyl bromide blocks the hyperpolarizing, but not the early or prolonged depolarizing components of the response (Fig. 13). Our observations suggest that arachidonic acid production is involved in mediating at least a substantial part of the increase in $\mathrm{K}^{+}$conductance that is evoked by FMRFamide, but not the change in $\mathrm{Na}^{+}$conductance. Arachidonic acid similarly mimics the effect of FMRFamide on the presynaptic sensory neurons, modulating three different $\mathrm{K}^{+}$conductances (Piomelli et al., 1987; Critz et al., 1991). However, the present evidence for a second messenger function for arachidonic acid in the LFS neurons is only suggestive since, in addition to its inhibitory effects on phospholipase $\mathrm{A}_{2}$, 4-bromophenacyl bromide has been demonstrated to have nonspecific effects in a variety of systems (see Blackwell and Flower, 1983, for review).

\section{FMRFamide effects on other molluscan neurons}

FMRFamide exerts modulatory effects on a wide variety of identified molluscan neurons and produces diverse types of responses in these neurons (e.g., Colombaioni et al., 1985; Thompson and Ruben, 1988; Haydon et al., 1991; Man-Son-Hing et al., 1992). In many molluscan neurons, FMRFamide causes an increase in $\mathrm{K}^{+}$conductance (Cottrell et al., 1984; Ruben et al., 1986; Brezina et al., 1987; Bahls et al., 1992; Simon et al., 1992). Ruben et al. (1986) described a biphasic response to FMRFamide in identified neurons L4 and L6 of Aplysia that is similar to the response we observed in LFS neurons: a transient increase in $\mathrm{Na}^{+}$conductance, followed by a prolonged increase in $\mathrm{K}^{+}$ conductance. In the B15 neuron of Aplysia, FMRFamide activates both an $\mathrm{S}$-like $\mathrm{K}^{+}$current and a $\mathrm{Na}^{+}$current; the $\mathrm{K}^{+}$ current component of the response may be mediated by arachidonic acid release (Taussig et al., 1989). FMRFamide also appears to produce an increase in a $\mathrm{K}^{+}$current in the B5 neuron in Heliosoma by stimulating release of arachidonic acid (Bahls et al., 1992). Therefore, although FMRFamide does not have the same effect on all molluscan neurons, certain patterns of response are often conserved.

\section{Variability in response of LFS neurons to FMRFamide}

There was a great deal of variability in the response to FMRFamide among the individual LFS neurons studied. For example, in the presence of $5 \mathrm{~mm} 4-\mathrm{AP}$ and low external $\mathrm{Na}^{+}$, 
a condition in which the 4-AP-sensitive current is blocked and $\mathrm{Na}^{+}$conductance substantially reduced, FMRFamide induced a prolonged outward current in half of the cells, and an inward current in the remaining half. Also, in normal saline, FMRFamide had an exclusively excitatory, rather than an excitatory/ inhibitory effect on $30 \%$ of the LFS neurons we studied. In these neurons, FMRFamide produced a biphasic response similar in time course to that of the excitatory/inhibitory response described in this article; however, the prolonged phase consisted of a depolarization instead of a hyperpolarization. This excitatory response is observed primarily during the summer months. Our analysis of this excitatory response will be described in more detail in a separate report (Belkin and Abrams, unpublished observations).

Alterations at several possible loci in the cellular pathways that mediate the response to FMRFamide could decrease the contribution of one component of the FMRFamide response relative to others. The different components of the FMRFamide response in LFS neurons involve separate ionic currents, separate coupling mechanisms between receptors and ion channels (e.g., different second messenger systems), and possibly separate receptor subtypes. Evidence for at least two distinct receptor subtypes comes from studics of Cottrell and Davics (1987), who found that different ionic responses to FMRFamide in Helix neurons varied in their relative sensitivity to several FMRFamide analogs. A change in any step in these independent pathways could account for the variability that we have observed.

\section{Possible behavioral role of LFS inhibition}

As yet there have been no FMRFamidergic neurons identified that modulate the LFS neurons. However, there is abundant FMRFamide-like immunoreactivity in neuronal processes in the regions of the abdominal ganglion neuropil where the LFS neurons arborize (Belkin, unpublished observations); thus, it is likely that under some circumstances, the LFS neurons are exposed to endogenously released tetrapeptide. We would expect that FMRFamide inhibition of LFS motor neuron activity would be capable of altering the behavioral output of the siphon withdrawal ncural circuit. LFS ncurons gencrally have a spontancous firing rate of less than $1 \mathrm{~Hz}$. Low-frequency firing of LFS neurons is not sufficient to stimulate contraction of siphon muscles; however, the background firing rate of LFS neurons is capable of influencing an evoked siphon withdrawal response. Frost et al. (1988) studied the effect of changes in the tonic firing rate of LFS neurons on siphon movements. They found that a minimum firing rate of $3 \mathrm{~Hz}$ was required for a single LFS cell to initiate a muscle contraction. Increasing the normal tonic firing rate of a cell within the subthreshold range (below $3 \mathrm{~Hz}$ ) resulted in enhancement of subsequent siphon movement produced by a given suprathreshold firing rate of the LFS neuron. This effect of tonic firing rate could be due to an elevation of resting $\mathrm{Ca}^{2+}$ levels in the motor neuron synaptic terminals or to the release of a modulatory cotransmitter at the neuromuscular junction. Therefore, the background firing rate of an LFS neuron plays a critical role in determining the magnitude of evoked siphon movements. The reduction in spontaneous firing of LFS neurons produced by FMRFamide would have a modulatory effect, causing a reduction in muscle contraction in response to a given suprathreshold LFS firing pattern.

It is worthwhile to note that although we have emphasized the inhibitory effects of FMRFamide on LFS motor neurons, its biphasic action raises the possibility that it could also have a significant excitatory effect. For example, it is possible that, under physiological conditions, exposure to the peptide might be sufficiently brief that FMRFamide would exert an exclusively excitatory effect on LFS neurons. It is not clear from our observations whether a very brief exposure to FMRFamide would activate the late phase of the response, nor whether a short burst of activity in the FMRFamidergic neurons providing input to the LFS cells would cause effective release of the peptide. Therefore, we can only speculate whether a brief burst of action potentials in FMRFamidergic neurons projecting to the LFS cells would result in a biphasic or an exclusively excitatory response. (In the subpopulation of LFS neurons in which the late hyperpolarizing phase of the response is absent, of course, FMRFamide has an exclusively excitatory effect.)

Inhibitory interactions within the ganglion play an important role in regulating the strength of the withdrawal reflex (Marcus et al., 1988; Small et al., 1989, 1992; Wright et al., 1991; Trudeau and Castellucci, 1992; Fischer and Carew, 1993). For example, recently Fischer and Carew (1993) found that an inhibitory feedback loop plays an important role in regulating the total synaptic input to the LFS motorneurons, and Trudeau and Castellucci (in press) found that cholinergic inhibition similarly influences the input to the motorncurons. Inhibition in the withdrawal circuit can be increased by behavioral stimuli; for example, a brief series of strong tail shocks (lasting $9 \mathrm{sec}$ ) causes a transient inhibition ( $<90 \mathrm{sec}$ ) of the siphon withdrawal reflex, followed by longer-lasting sensitization (Marcus et al., 1988). Several lines of evidence indicate that FMRFamidergic hyperpolarization of LFS motor neurons cannot account for the behavioral inhibition resulting from tail shock. Tail shock caused excitation, rather than an inhibition of LFS neurons (Frost et al., 1988), even though the magnitude of the stimulation was comparable to that which produced behavioral inhibition of the withdrawal reflex (Marcus et al., 1988; Wright et al., 1991). Also, aversive stimulation that results in behavioral inhibition has been demonstrated to reduce the complex EPSP produced in LFS neurons by tactile stimulation of the siphon, but not the monosynaptic EPSP from the siphon sensory neurons (Wright et al., 1991), suggesting that dircet modulation of the LFS neurons is not responsible for the inhibition of reflex activity. In contrast, the results of other investigators indirectly suggest that inhibitory tail shock does modulate the synaptic connections from the siphon sensory neurons. A FMRFamidergic interneuron LPL 16 has been identified that is activated by tail shock, and that causes both narrowing of the sensory neuron action potential and inhibition of the monosynaptic EPSP in the LFS neurons (Mackey et al., 1987; Small et al., 1992). LPL16 apparently does not modulate LFS neurons since activity in this interneuron did not alter the input resistance of the motor neurons (Small et al., 1992). Therefore, FMRFamidergic inhibition of LFS neurons does not appear to be involved in the inhibition of siphon withdrawal in response to tail shock. This does not mean that inhibition of LFS neurons has no behavioral relevance, since there are other behavioral circumstances (other than tail shock) in which inhibition of the withdrawal reflex occurs. For example, the magnitude of the withdrawal response is reduced immediately following feeding (Advokat, 1980) and the response may also be inhibited during burrowing (Aspey and Blankenship, 1976).

There are several possible adaptive advantages of having a single neurotransmitter exert parallel effects on both sensory and motor neurons of a single neural pathway. The role of 
multiple sites of modulation in altering the behavioral output of a neural circuit depends on whether the transmitter is released at the different sites simultaneously. If both the sensory and motor neurons received FMRFamidergic inputs at the same time, having multiple sites of modulation would serve to amplify the overall inhibition of the siphon withdrawal reflex. Serotonergic modulation of the circuit mediating fccding bchavior in Aplysia provides an example of simultaneous release at multiple sites; a single neuron, the metacerebral cell, releases 5-HT at synaptic sites on both motor neurons and the muscle itself. 5-HT acts at both sites of this neural circuit to increase the rate of biting (Weiss et al., 1978; Rosen et al., 1989).

An alternative possibility is that the release of FMRFamide onto the multiple sites within the circuit is differentially regulated, and therefore FMRFamide could modulate one neural element in the circuit independently of the others. As described above, Mackey et al. (1987) have identified a FMRFamidergic neuron in the pleural ganglion, LPL16, which inhibits the monosynaptic postsynaptic potential between LE siphon sensory neurons and LFS siphon motor neurons. This neuron has presynaptic, but no postsynaptic effects at this synapse (Mackey et al., 1987; Small et al., 1992). Such a pattern of innervation would increase the range of plasticity of which the system is capable, and allow for a greater variety of behavioral outputs.

\section{References}

Abrams TW, Castellucci VF, Camardo JS, Kandel ER, Lloyd PE (1984) Two endogenous neuropeptides modulate the gill and siphon withdrawal reflex in Aplysia by presynaptic facilitation involving cAMPdependent closure of a serotonin-sensitive potassium channel. Proc Natl Acad Sci USA 81:7956-7960.

Advokat C (1980) Modulation of defensive reflexes in Aplysia californica by appetitive stimulation. Behav Neural Biol 28:253-265.

Armitage B, Buttner N, Siegelbaum SA (1991) Dual modulation of a hyperpolarization-activated $\mathrm{Cl}^{-}$current by cAMP and cGMP in $\mathrm{Aply}$ sia sensory neurons. Soc Neurosci Abstr 17:1096.

Aspey WP, Blankenship JE (1976) Aplysia behavioral biology. I. A multivariate analysis of burrowing in A. brasiliana. Behav Biol 17: 279-299.

Bahls FH, Richmond JE, Smith WL, Haydon PG (1992) A lipoxygenase pathway of arachidonic acid metabolism mediates FMR Famide activation of a potassium current in an identified neuron of $\mathrm{Hel}$ isoma. Neurosci Lett 138:165-168.

Baxter DA, Byrne JH (1989) Serotonergic modulation of two potassium currents in the pleural sensory neurons of Aplysia. J Neurophysiol 62:665-679.

Belardetti F, Kandel ER, Siegelbaum SA (1987) Neuronal inhibition by the peptide FMRFamide involves opening of $\mathrm{S} \mathrm{K}^{+}$channels. Nature 325:153-156.

Belardetti F, Campbell WB, Falck JR, Demontis G, Rosolowsky M (1989) Products of heme-catalyzed transformation of the arachidonate derivative 12-HPETE open S-type $\mathrm{K}^{+}$channels in Aplysia. Neuron 3:497-505.

Bernier L, Castellucci VF, Kandel ER, Schwartz JH (1982) Facilitatory transmitter causes a selective and prolonged increase in adenosine $3^{\prime}$ : 5 '-monophosphate in sensory neurons mediating the gill and siphon withdrawal reflex in Aplysia. J Neurosci 2:1682-1691.

Blackwell GJ, Hlower RJ (1983) Inhibition of phospholipase. Br Med Bull 39:260-264.

Brezina V, Eckert R, Erxleben C (1987) Modulation of potassium conductances by an endogenous neuropeptide in neurones of Aplysia californica. J Physiol (Lond) 382:267-290.

Brunelli M, Castellucci V, Kandel ER (1976) Synaptic facilitation and behavioral sensitization in Aplysia: possible role of serotonin and cyclic AMP. Science 194:1178-1181.

Buttner N, Siegelbaum SA (1990) FMRFamide and cGMP activate inward current in Aplysia sensory neurons. Soc Neurosci Abstr 16: 794.

Buttner N, Siegelbaum SA, Volterra A (1989) Direct modulation of
Aplysia S-K ${ }^{+}$channels by a 12 -lipoxygenase metabolite of arachidonic acid. Nature 342:553-555.

Byrne JH, Cleary LJ, Baxter DA (1990) Aspects of the neural and molecular mechanisms of short-term sensitization in Aplysia: modulatory effects of serotonin and cAMP on duration of action potentials, excitability and membrane currents in tail sensory neurons. In: The biology of memory (Squire LR, Lindenlaub E, eds), pp 7-28. New York: Schattauer.

Carew TJ, Walters ET, Kandel ER (1981a) Associative learning in Aplysia: cellular correlates supporting a conditioned fear hypothesis. Science 211:501-504.

Carew TJ, Walters ET, Kandel ER (1981b) Classical conditioning in a simple withdrawal reflex in Aplysia californica. J Neurosci 1:14261437.

Castellucci V, Kandel ER (1976) Presynaptic facilitation as a mechanism for behavioral sensitization in Aplysia. Science 194:1176-1178.

Castellucci V, Pinsker H, Kupfermann I, Kandel ER (1970) Neuronal mechanisms of habituation and dishabituation of the gill-withdrawal reflex in Aplysia. Science 167:1745-1748.

Colombaioni L, Paupardin TD, Vidal PP, Gerschenfeld HM (1985) The neuropeptide FMRF-amide decreases both the $\mathrm{Ca}^{2+}$ conductance and a cyclic $3^{\prime}, 5^{\prime}$-adenosine monophosphate-dependent $\mathrm{K}^{+}$conductance in identified molluscan neurons. J Neurosci 5:2533-2538.

Connor JA, Stevens CF (1971) Voltage clamp studies of a transient outward membranc current in gastropod neural somata. J Physiol (Lond) 213:21-30.

Cottrell GA, Davies NW (1987) Multiple receptor sites for a molluscan peptide (FMRFamide) and related peptides of Helix. J Physiol (Lond) 382:51-68.

Cottrell GA, Davies NW, Green KA (1984) Multiple actions of a molluscan cardioexcitatory neuropeptide and related peptides on identified Helix neurones. J Physiol (Lond) 356:315-333.

Critz SD, Baxter DA, Byrne JH (1991) Modulatory effects of serotonin, FMRFamide, and myomodulin on the duration of action potentials, excitability, and membrane currents in tail sensory neurons of Aplysia. J Neurophysiol 66:1912-1926.

Dale N, Kandel ER (1990) Facilitatory and inhibitory transmitters modulate spontaneous transmitter release at cultured Aplysia sensorimotor synapses. J Physiol (Lond) 421:203-222.

Edmonds B, Klein M, Dale N, Kandel ER (1990) Contributions of two types of $\mathrm{Ca}^{2+}$ channels to synaptic transmission and plasticity. Science 250:1142-1147.

Fang X, Clark GA (1990) Neural mechanisms of response specificity I. Tail and mantle nerve shock produce differential effects on the siphon-withdrawal neuronal circuit in Aplysia. Soc Neurosci Abstr 16:596.

Fang X, Clark GA (1992) Neural mechanisms of response specificity. Il. Cutaneous tail and mantle shock produce differential effects on the siphon-withdrawal neuronal circuit in Aplysia. Soc Neurosci Abstr 18:713.

Fischer TM, Carew TJ (1993) Activity-dependent potentiation of recurrent inhibition: a mechanism for dynamic gain control in the siphon withdrawal reflex of Aplysia. J Neurosci 13:1302-1314.

Frost WN, Clark GA, Kandel ER (1988) Parallel processing of shortterm memory for sensitization in Aplysia. J Neurobiol 19:297-334.

Glanzman DL, Mackey SL, Hawkins RD, Dyke AM, Lloyd PE, Kandel ER (1989) Depletion of serotonin in the nervous system of Aplysia reduces the behavioral enhancement of gill withdrawal as well as the heterosynaptic facilitation produced by tail shock. J Neurosci 9.

Goldsmith BA, Abrams TW (1992) cAMP modulates multiple $\mathrm{K}^{+}$ current, increasing spike duration and excitability in Aplysia sensory neurons. Proc Natl Acad Sci USA 89:11481-11485.

Hawkins RD (1989) Localization of potential serotonergic facilitator neurons in Aplysia by glyoxylic acid histofluorescence combined with retrograde fluorescent labeling. J Neurosci 9:4214-4226.

Hawkins RD, Castellucci VF, Kandel ER (1981) Interneurons involved in mediation and modulation of gill-withdrawal reflex in Aplysia. I. Identification and characterization. J Neurophysiol 45:304314.

Haydon PG, Man-Son-Hing H, Doyle RT, Zoran M (1991) FMRFamide modulation of sccrctory machinery underlying presynaptic inhibition of synaptic transmission requires a pertussis toxin-sensitive G-protein. J Neurosci 11:3851-3860

Hedqvist P (1977) Basic mechanisms of prostaglandin action on au- 
tonomic neurotransmission. Annu Rev Pharmacol Toxicol 17:259279.

Hermann A, Gorman ALF (1981a) Effects of 4-aminopyridine on potassium currents in a molluscan neuron. J Gen Physiol 78:63-86.

Hermann A, Gorman ALF (1981b) Effects of tetraethylammonium on potassium currents in a molluscan neuron. J Gen Physiol 78:87110.

Hickie C, Walters ET (1990) Identified central motor neurons are necessary for directional siphon responses in Aplysia. Soc Neurosci Abstr 16:19.

Hickie C, Walters ET (1991) Response-specific learning in Aplysia: frequency-dependent effects of directional siphon motor neurons. Soc Neurosci Abstr 17:548.

Jarrard HE, Goldsmith B $\Lambda$, $\Lambda$ brams TW (1993) In Aplysia sensory neurons, the neuropeptide $\mathrm{SCP}_{\mathrm{B}}$ and serotonin differ in efficacy both in modulating cellular properties and in activating adenylyl cyclase: implications for mechanisms underlying presynaptic facilitation. Brain Res 616:188-199.

Klein M, Kandel ER (1980) Mechanism of calcium current modulation underlying presynaptic facilitation and behavioral sensitization in Aplysia. Proc Natl Acad Sci USA 77:6912-6916.

Klein M. Camardo J, Kandel ER (1982) Serotonin modulates a specific potassium current in the sensory neurons that show presynaptic facilitation in Aplysia. Proc Natl Acad Sci USA 79:5713-5717.

Klein M, Hochner B, Kandel ER (1986) Facilitatory transmitters and cAMP can modulate accommodation as well as transmitter release in Aplysia sensory neurons: evidence for parallel processing in a single ccll. Proc Natl Acad Sci USA 83:7994-7998.

Krontiris LJ, Cooper BF, Walters ET (1989) Humoral factors released during trauma of Aplysia body wall. I. Body wall contraction, cardiac modulation, and central reflex suppression. J Comp Physiol [B] 159: 211-223.

Mackey SL, Glanzman DL, Small SA, Dyke AM, Kandel ER, Hawkins RD (1987) Tail shock produces inhibition as well as sensitization of the siphon-withdrawal reflex of Aplysia: possible behavioral role for presynaptic inhibition mediated by the peptide Phe-Met-Arg-Phe$\mathrm{NH}_{2}$. Proc Natl Acad Sci USA 84:8730-8734.

Mackey SL, Kandel ER, Hawkins RD (1989) Identified serotonergic neurons LCB1 and RCB1 in the cerebral ganglia of Aplysia produce presynaptic facilitation of siphon sensory neurons. J Neurosci 9:42274235 .

Man-Son-Hing H, Haydon PG (1992) Modulation of growth cone calcium current is mediated by a PTX-sensitive G protein. Neurosci Lett 137:133-136.

Marcus EA, Nolen TG, Rankin CH, Carew TJ (1988) Behavioral dissociation of dishabituation, sensitization, and inhibition in Aplysia. Science 241:210-213.

Marder E, Meyrand P (1989) Chemical modulation of an oscillatory neural circuit. In: Neuronal and cellular oscillators (Jacklet JW, ed), pp 317-338. New York: Dekker.

Mercer AR, Emptage NJ, Carew TJ (1991) Pharmacological distinction of modulatory effects of serotonin in Aplysia sensory neurons. Science 254:1811-1813

Ocorr KA, Byrne JH (1985) Membrane responses and changes in cAMP levels in Aplysia sensory neurons produced by serotonin, tryptamine, FMRFamide and small cardioactive peptide B (SCPB). Neurosci Lett 55:113-118.

Perlman AJ (1979) Central and peripheral control of siphon-withdrawal reflex in Aplysia californica. J Neurophysiol 42:510-529.

Pieroni JP, Byrne JH (1992) Differential effects of serotonin, FMRFamide and small cardioactive peptide on multiple, distributed processes modulating sensorimotor synaptic transmission in Aplysia. J Neurosci 12:2633-2647.

Pinsker H, Kandel ER, Castellucci V, Kupfermann I (1970) An analysis of habituation and dishabituation in Aplysia. Adv Biochem Psychopharmacol 2:351-373.

Piomelli D, Volterra A, Dale N, Siegelbaum SA, Kandel ER, Schwartz $\mathrm{JH}$, Belardetti F (1987) Lipoxygenase metabolites of arachidonic acid as second messengers for presynaptic inhibition of Aplysia sensory cells. Nature $328: 38-43$.

Pollock JD, Bernier L, Camardo JS (1985) Serotonin and cyclic adenosine $3^{\prime}: 5^{\prime}$-monophosphate modulate the potassium current in tail sensory neurons in the pleural ganglion of Aplysia. J Neurosci 5:18621871

Rosen SC, Weiss KR, Goldstein RS, Kupfermann I (1989) The role of a modulatory neuron in feeding and satiation in Aplysia: effects of lesioning of the serotonergic metacerebral cells. J Neurosci 9:15621578.

Ruben P, Johnson IW, Thompson S (1986) Analysis of FMRF-amide effects on Aplysia bursting neurons. J Neurosci 6:252-259.

Selverston AI (1989) Lobster gastric mill oscillator. In: Neuronal and cellular oscillators (Jacklet, eds), pp 339-70. New York: Dekker.

Shuster MJ, Siegelbaum SA (1987) Pharmacological characterization of the serotonin-sensitive potassium channel of Aplysia sensory neurons. J Gen Physiol 90:587-608.

Shuster MJ, Camardo JS, Siegelbaum SA (1991) Comparison of the serotonin-sensitive and $\mathrm{Ca}\left({ }^{2+}\right)$-activated $\mathrm{K}^{+}$channels in Aplysia sensory neurons. J Physiol (Lond) 440:601-621.

Siegelbaum SA, Camardo JS, Kandel ER (1982) Serotonin and cyclic AMP close single $\mathrm{K}^{+}$channels in Aplysia sensory neurones. Nature 299:413-417.

Simon T, Opdyke CA, Calabrese RL (1992) Modulatory effects of FMRF- $\mathrm{NH}_{2}$ on outward currents and oscillatory activity in heart interneurons of the medicinal leech. J Neurosci 12:525-537.

Small SA, Kandel ER, Hawkins RD (1989) Activity-dependent enhancement of presynaptic inhibition in Aplysia sensory neurons. Science 243:1603-1606.

Small SA, Cohen TE, Kandel ER, Hawkins RD (1992) Identified FMRFamide-immunoreactive neuron LPL16 in the left pleural ganglion of Aplysia produces presynaptic inhibition of siphon sensory neurons. J Neurosci 12:1616-1627.

Sweatt JD, Volterra A, Edmonds B, Karl KA, Siegelbaum SA, Kandel ER (1989) FMRFamide reverses protein phosphorylation produced by 5-HT and cAMP in Aplysia sensory neurons. Nature 342:275278.

Taussig R, Sweet CA, Scheller RH (1989) Modulation of ionic currents in Aplysia motor neuron B15 by serotonin, neuropeptides, and second messengers. J Neurosci 9:3218-3229.

Thompson S (1977) Three pharmacologically distinct potassium channels in molluscan neurones. J Physiol (Lond) 265:465-488.

Thompson S, Ruben P (1988) Inward rectification in response to FMRFamide in Aplysia neuron L2: summation with transient $\mathrm{K}$ current. J Neurosci 8:3200-3207.

Trudeau L-E, Castellucci VF (1993) Functional uncoupling of inhibitory interneurons plays an important role in short-term sensitization of Aplysia gill and siphon withdrawal reflex. J Neurosci 13:21262135.

Walsh JP, Byrne JH (1985) Analysis of decreased conductance serotonergic response in Aplysia ink motor neurons. J Neurophysiol 53: 590-602.

Walsh JP, Byrne JH (1989) Modulation of a steady-state $\mathrm{Ca}^{2+}$-activated, $\mathrm{K}^{+}$current in tail sensory neurons of Aplysia: role of serotonin and cAMP. J Neurophysiol 61:32-44.

Walters ET, Byrne JH, Carew TJ, Kandel ER (1983) Mechanoafferent neurons innervating tail of Aplysia. II. Modulation by sensitizing stimulation. J Neurophysiol 50:1543-1559.

Weiss KR, Cohen JL, Kupfermann I (1978) Modulatory control of buccal musculature by a serotonergic neuron (metacerebral cell) in Aplysia. J Neurophysiol 41:181-203.

Wright WG, Marcus EA, Carew TJ (1991) A cellular analysis of inhibition in the siphon withdrawal reflex of Aplysia. J Neurosci 11 : 2498-2509.

Yarom Y, Sugimori M, Llinás R (1985) Ionic currents and firing patterns of mammalian vagal motoneurons in vitro. Neuroscience 16 : $719-737$. 